\title{
The Moroccan Massive Sulphide Deposits: Evidence for a Polyphase Mineralization
}

\author{
Abderrahim Essaifi ${ }^{1, *}\left(\mathbb{0}\right.$, Kathryn Goodenough ${ }^{2}$, Fernando Tornos ${ }^{3}{ }^{\circ}$, Abdelhak Outigua ${ }^{4}$, \\ Abdelmalek Ouadjou ${ }^{4}$ and Lhou Maacha ${ }^{4}$ \\ 1 Geology Department, Cadi Ayyad University, BP. 2390, Marrakech 40000, Morocco \\ 2 British Geological Survey, The Lyell Centre Research Avenue South, Edinburgh EH14 4AP, UK; \\ kmgo@bgs.ac.uk \\ 3 Instituto de Geociencias (IGEO, CSIC-UCM), Calle Dr Severo Ochoa, 7, 28040 Madrid, Spain; f.tornos@csic.es \\ 4 Managem Group, BP. 5199, Casablanca 20100, Morocco; A.OUTIGUA@managemgroup.com (A.O.); \\ a.ouadjou@managemgroup.com (A.O.); L.Maacha@managemgroup.com (L.M.) \\ * Correspondence: essaifi@uca.ac.ma; Tel.: +212-524-443-449
}

Received: 28 January 2019; Accepted: 3 March 2019; Published: 6 March 2019

check for updates

\begin{abstract}
This work provides an overview of the geological, geochemical, and metallogenic data available up to date on the Moroccan massive sulphide deposits, including some new results, and then discusses the evidences for the epigenetic and syngenetic hypotheses. All of the ore deposits are located within a crustal block located at the intersection between two major shear zones and are characterized by a sustained and long-lived magmatic activity. The ore deposits are located within second-order shear zones, which played an important role in controlling the geometry of the mineralization. The mineralization lacks the unequivocal textural and structural features that are indicative of a sedimentary or diagenetic origin, and a syntectonic to late-tectonic pyrite-rich assemblage is superimposed on an earlier, pretectonic to syntectonic pyrrhotite-rich mineralization. Each deposit has a distinctive pyrrhotite sulfur isotopic signature, while the sulfur isotopic signature of pyrite is similar in all deposits. Lead isotopes suggest a shift from a magmatic source during the pyrrhotite-rich mineralization to a source that is inherited from the host shales during the pyrite-rich mineralization. The $\mathrm{O} / \mathrm{H}$ isotopic signatures record a predominance of fluids of metamorphic derivation. These results are consistent with a model in which an earlier pyrrhotite-rich mineralization, which formed during transtension, was deformed and then remobilized to pyrite-rich mineralization during transpression.
\end{abstract}

Keywords: polymetallic massive sulphide deposits; shear zones; geochemistry; Moroccan Meseta; Hercynian

\section{Introduction}

Volcanogenic massive sulphide (VMS) deposits are an important source of copper, zinc, lead, gold, and silver [1-4]. They widely vary in size and are found throughout the geological record, from the Archaean to the present day [5,6]. Many VMS deposits are forming today in relationship with submarine hydrothermal systems, in settings, including mid-ocean ridges, back-arc basins, and volcanic arcs [7]. Extensive research has identified VMS deposits that formed in a range of geodynamic settings over geological time, and a number of classifications have been developed for these deposits $[1,3,8]$. These classifications are typically based on the metal contents, lithostratigraphy, and the tectonic setting. In the geological record, most of the deposits that formed at mid-ocean ridges have not been preserved, and so deposits that are associated with back-arc or arc-marginal basins and intracontinental basins are the most common [5]. Although there has been significant debate in the 
past regarding the importance of epigenetic massive sulphide deposits, the majority of deformed VMS deposits are now considered to be syngenetic [1,6].

Many VMS deposits are found in zones that have undergone intense and polyphase deformation, such as the Bathurst mining camp in Canada [9] or the Iberian Pyrite Belt [10]. In such cases, detailed mapping and structural studies are required to distinguish remobilized synvolcanic deposits from epigenetic or syntectonic mineralization [11-13].

The Variscan belt of southern Europe and North Africa contains many examples of deformed VMS deposits, with the best-known examples lying within the Iberian Pyrite Belt $[10,14,15]$. Well-exposed massive sulphide deposits are found in the southern Meseta where this belt continues into Morocco (Figure 1) [16]. Among these deposits the Kettara deposit was mined from 1938 to 1982 [17], and mining is currently active at the Draa Sfar and Hajjar mines [18-21]. Numerous other targets have been the subject of exploration and drilling. The deposits are typically vertical or steeply dipping, pyrrhotite-dominated and they have clearly been affected by the superimposed Variscan deformation [21]. This has led to two contrasting hypotheses for their origin. The syngenetic hypothesis proposes that these are classic volcanogenic massive sulphide deposits that formed at or below the seafloor in an anoxic basin, with the hydrothermal system being driven by contemporaneous volcanism. This hypothesis seems to be supported by different evidences at Hajjar [22-24] and Draa Sfar [18-20], where the sulphide deposits are spatially associated with felsic volcanic rocks. In contrast, the epigenetic hypothesis suggests that the massive sulphides were formed during deformation, with the hydrothermal system being driven by heat from syn-tectonic intrusions. Evidence for this comes from areas that are devoid of volcanic and volcaniclastic rocks, particularly at Kettara [17,25]. An "intermediate" hypothesis has been proposed for the Koudiat Aïcha deposit, which has been described as a "Besshi-type" VMS, which is related to the mafic intrusions in the area [26,27]. In order to investigate the evidence for these contrasting hypotheses, we present a synthesis that integrates existing and new geological and metallogenic information of the Moroccan massive sulphide deposits (MMSD). This synthesis shows that the MMSD present unique features that differentiate them from those of the Iberian Pyrite Belt (IPB) and are difficult to interpret in terms of the classical VMS model. 

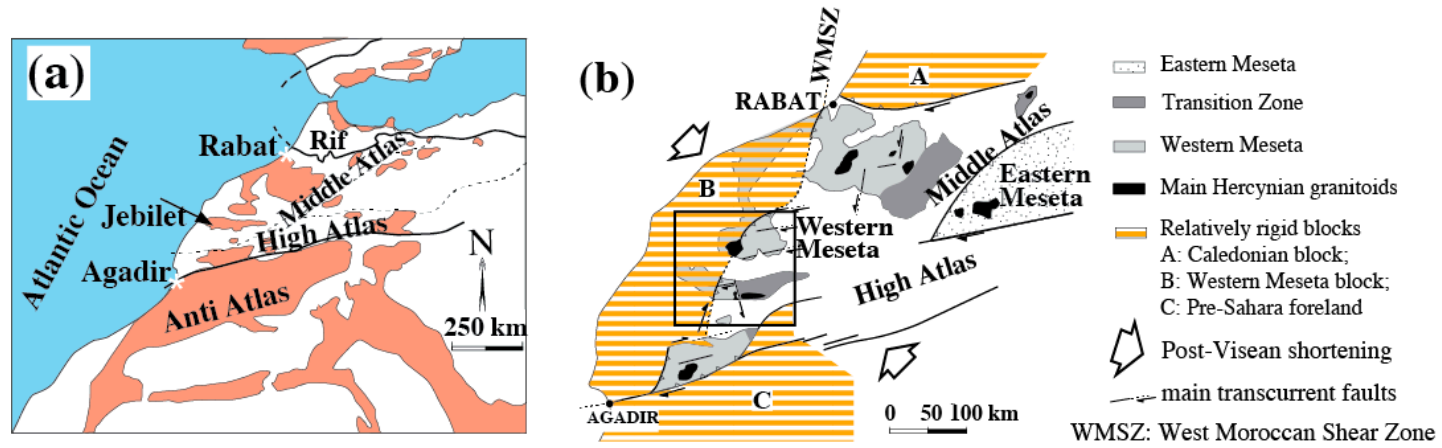

(c)

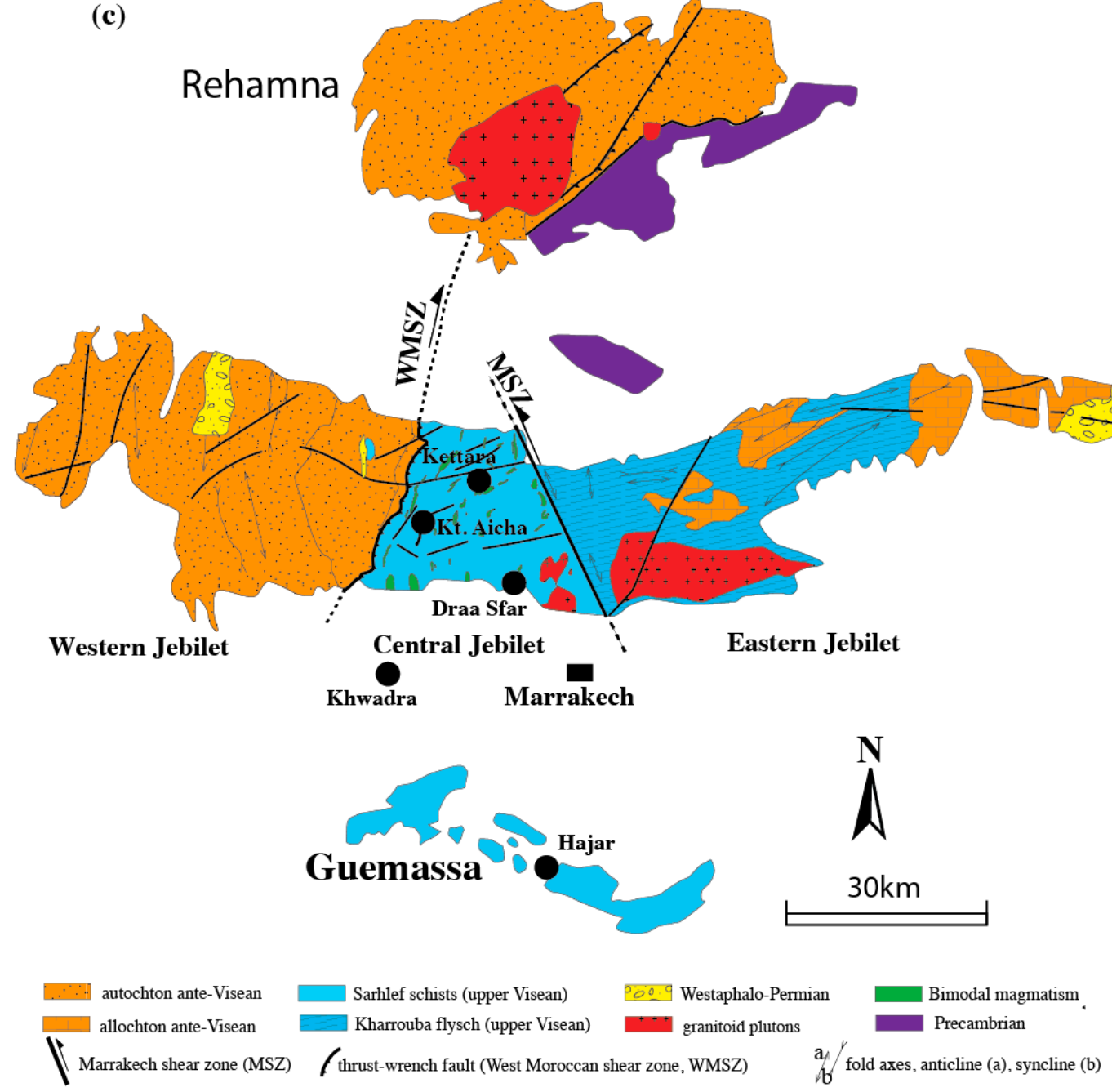

Figure 1. (a) Geology of the Jebilet Massif in the framework of the Paleozoic outcrops of North Africa, (b) Main structural zones of the Variscan Belt of Morocco (modified from [28]), and (c) General geological map of the Rehamna, Jebilet and Guemassa massifs showing the location of the principal massive sulphide deposits (modified from $[16,29]$ ). The white color represents undifferentiated post-Paleozoic sedimentary units.

\section{Geological Setting}

The Variscan collisional belt in Morocco is exposed in several Paleozoic massifs that lie to the west and to the east of the folded Mesozoic-Cenozoic cover of the middle Atlas, forming, respectively, the Western and the Eastern Meseta domains (Figure 1a). The Meseta domains display a nearly complete Paleozoic 
sedimentary sequence, which is folded and metamorphosed at greenschist to amphibolite facies during a polyphased Variscan (Hercynian) orogeny, and intruded by widespread, syn- to late-orogenic Carboniferous granitoids [28,30,31]. The occurrence of an Eo-Variscan tectono-metamorphic event dated at 366-372 Ma characterizes the eastern Meseta [32,33]. Two tectono-metamorphic events occurred at $330 \mathrm{Ma}$ and $300 \mathrm{Ma}$ in the western Meseta domain [33]. The western Meseta has been subdivided into the Nappe Zone, the Central Zone and the Coastal Block [28], with the Central Zone and Coastal Block being separated by a major structure known as the Western Meseta Shear Zone [34].

The Jebilet massif, which is to the north of Marrakech, provides a well-exposed cross-section across the western Meseta [16,35] (Figure 1c). The Western Jebilet Unit includes a sequence of Cambro-Ordovician sedimentary rocks that was uplifted in the Late Devonian and only weakly deformed in the Variscan $[16,28,36]$. It is separated from the Central Jebilet Unit by a dextral thrust-wrench fault [37,38], which is part of the Western Meseta Shear Zone [34]. The Central Jebilet Unit is part of the Central Zone and it comprises sedimentary rocks of the Visean age [16,39], which have been metamorphosed to low grade and extensively deformed in the Variscan orogeny $[35,40]$. The Eastern Jebilet Unit is part of the Nappe Zone; it contains an Upper Visean sedimentary sequence, the "Kharrouba Flysch" [16], which grades from turbidites to tidally-influenced shallow marine deposits [41-44]. This is overlain by tectonically-emplaced nappes, including Ordovician to early Carboniferous sedimentary rocks with a chaotic basal breccia $[41,45]$. These nappes mark the onset of the closure of the Mesetian basin $[28,46,47]$. The Eastern Jebilet Unit is separated from the Central Jebilet Unit by the Marrakech Shear Zone [35,48]. Westphalian-Permian continental conglomerates [16] unconformably rest upon the Hercynian folded sequence in the Eastern and Western Jebilet Units.

The Central Jebilet Unit, which hosts the MMSD (Figure 2), is a thick (>1000 m) largely low-grade metamorphosed Upper Visean metasedimentary sequence that is dominated by schists with subsidiary limestone and sandstone beds, named the Sarhlef Schists [16,43]. The protoliths of these schists were considered to be shales, locally black, indicating that this succession was deposited in an anoxic basin, with storm deposits representing the sandstones [44,49]. Bordonaro et al. [50] revised the stratigraphy of Central Jebilet and allocated the name Sarhlef Formation to the detrital sequence (at least $1000 \mathrm{~m}$ thick) and Teksim Formation (correlated with the Teksim Formation of the Eastern Jebilet) to the upper calcareous member that is composed of carbonaceous argillites and limestones (100 m), which defines the top of an interpreted basin-fill succession. The Sarhlef Formation was subsequently further subdivided into an Upper Member and a Lower Member [19-21,51]. The Lower Member consists of shales, sandstones, felsic, and mafic tuffs, and the Upper Member comprises shales, siltstones, sandstones, and felsic volcanic rocks, as can be seen in Draa Sfar and Koudiat Delaa. The entire sequence was intruded by mafic and felsic magmas that form dykes, sills, and plutons. Although the major part of the Sarhlef Schists has been described as a metamorphosed volcanosedimentary sequence [16,51], the majority of the igneous rocks of Central Jebilet are intrusive rocks and only minor rhyolitic and rhyodacitic domes and volcaniclastic units are present $[52,53]$. 


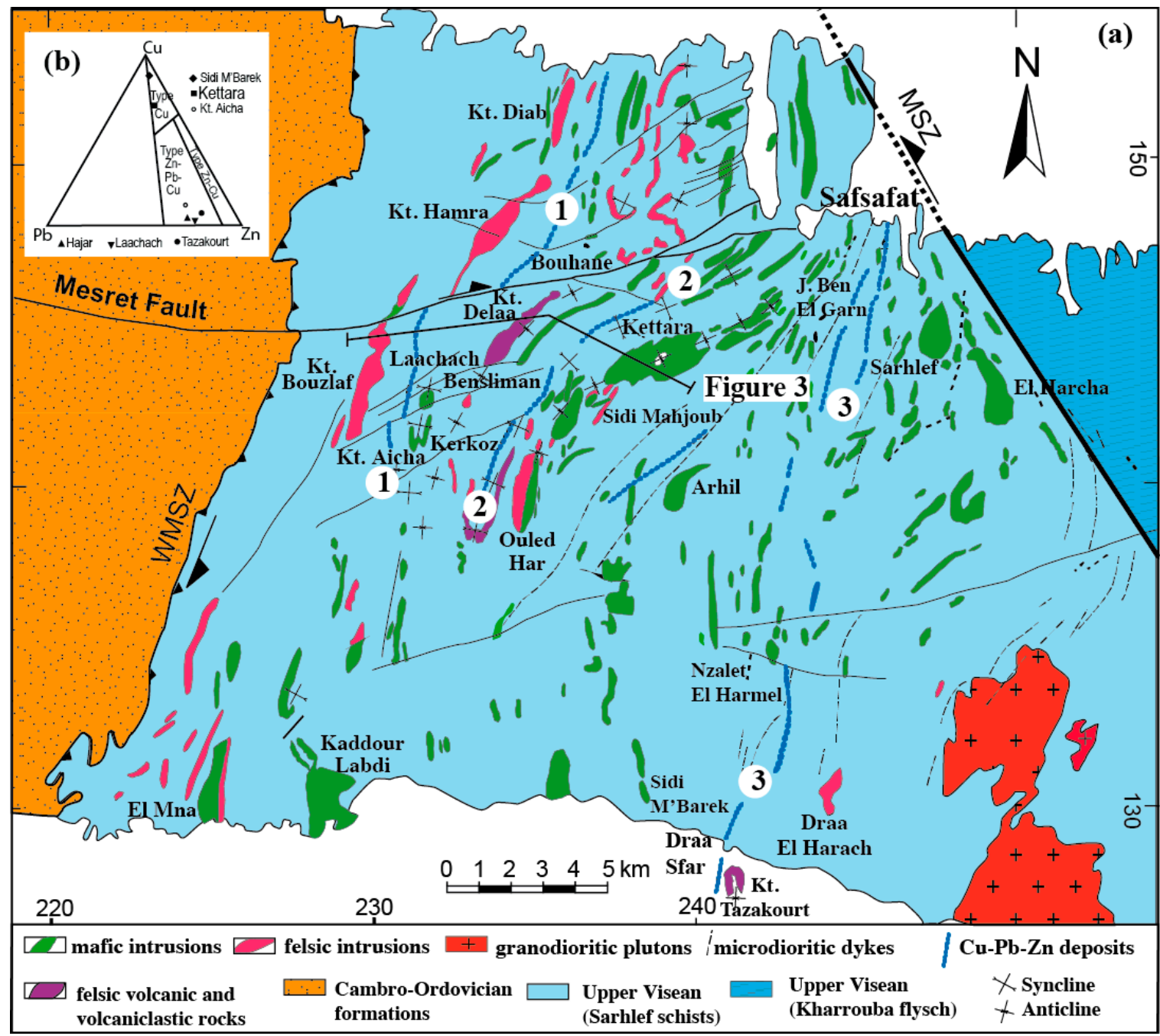

Figure 2. (a) Regional distribution of the massive sulphide deposits in the Central Jebilet (modified from [16]). The numbers 1, 2, 3 refer to the western, central, and eastern lineaments controlling the massive sulphide orebodies. (b) Plot of the main sulphide deposits in the $\mathrm{Cu}-\mathrm{Pb}-\mathrm{Zn}$ classification of Large [54]. The white color represents undifferentiated post-Paleozoic sedimentary units.

The Variscan intrusive rocks in Central Jebilet can be subdivided in two groups [53]. The first one is a bimodal association of mafic-ultramafic plutons, sills, and dykes that coexist with sheet-like alkaline microgranitic intrusions and dykes. The microgranitic rocks contain minerals that are characteristic of alkaline magmatism, most notably alkali amphibole, with fluorite and apatite as accessories [53]. The microgranites have been dated at $330.5+0.68 /-0.83 \mathrm{Ma}$ (U-Pb on zircon) [55], and more recently a single sample from the Koudiat Hamra intrusion has been dated at $345 \pm 2 \mathrm{Ma}$ [56]. The second group of intrusions comprises two cordierite-bearing granodioritic plutons that are crosscut by leucogranitic dykes. Rb-Sr dating had suggested an age of ca. $327 \pm 4 \mathrm{Ma}$ for the granodioritic plutons and $295 \pm 15 \mathrm{Ma}$ for the cross-cutting leucogranites [57], although more recent U-Pb dating has suggested somewhat older ages of 358-336 Ma for the granodiorites [56]. In any case, geochronological dating indicates a sustained and long-lasting magmatic activity in the Jebilet massif, between $358 \pm 7 \mathrm{Ma}$ and ca. $300 \mathrm{Ma}$ [55-57]. The felsic magmatism is characterized by a temporal evolution from magmas of hybrid origin to magmas of pure crustal origin, reflecting a lithosphere that is heated from below. Such an evolution was related to the cessation of continental subduction, slab-breakoff, asthenospheric upwelling, and development of strike-slip faulting during plate convergence [53]. 
The Sarhlef Schists underwent low-grade metamorphism and deformation during the Variscan orogeny $[16,26,40,51]$. Huvelin identified the presence of two major phases of deformation and folding [16]. The main regional cleavage $\left(\mathrm{S}_{1}\right)$ typically trends NNE-SSW and is axial planar to a series of open upright F1 folds [35,48]. This cleavage bends into a series of shear zones, which have been divided into two groups [35]. There is group of typically N-S trending sinistral shear zones that is well developed across much of the Central Jebilet, but they are subsequently affected by dextral shearing that is associated with late major faults, such as the Mesret Fault [17,26,35]. The shear zones are associated with an increasing of strain, tightening of folds, and development of stretching lineations, which can be considered as being related to a $\mathrm{D}_{2}$ phase $[26,35,56]$. A late brittle $\mathrm{D}_{3}$ episode is also recognized in the Jebilet Massif.

\section{Massive Sulphide Deposits}

\subsection{Size and Tonnage}

All of the MMSD deposits are covered by well-developed gossans, either outcropping on surface (Kettara, Koudiat Aicha, Draa Sfar North) or covered with Plio-Quaternary sediments (Hajjar, Draa Sfar South). At least four deposits are mineable: Kettara, Koudiat Aicha, Hajar, and Draa Sfar (Table 1).

Table 1. Ore reserves and average grade of selected deposits in the Jebilet-Guemassa district.

\begin{tabular}{cccccc}
\hline Deposit & Reservers (Mt) & $\mathbf{C u} \mathbf{w t} \%$ & $\mathbf{Z n ~ w t ~} \%$ & $\mathbf{P b}$ wt $\%$ & Ag g/t \\
\hline Draa Sfar South & 19 & 0.35 & 5.28 & 1.75 & 36 \\
\hline Draa Sfar Nouth $(\mathrm{Cu})$ & 1 & 2 & 0.2 & 0.25 & 6 \\
\hline Draa Sfar Nouth $(\mathrm{Zn})$ & 0.35 & 0.3 & 4.46 & 2.02 & 32 \\
\hline Kettara & 30 & 0.7 & 0.2 & 0.1 & 20 \\
\hline Koudiat Aicha & 4.5 & 0.5 & 2.7 & 1 & 25 \\
\hline Hajar & 20 & 0.5 & 8 & 3 & 48 \\
\hline Laachach & 0.38 & 0.2 & 3.8 & 1.2 & 25 \\
\hline
\end{tabular}

Having a well-developed gossan and a location that is close to the Marrakech-Safi road, the Kettara deposit was the first massive sulphide deposit to be discovered and mined [17]. The gossan was exploited for limonite and ochre from 1938 to 1963. Below the gossan, there is a cementation zone that includes native copper, pyrite, chalcocite $\left(\mathrm{Cu}_{2} \mathrm{~S}\right)$, covellite (CuS), with traces of gold and silver [58]. Pyrite was extracted from this zone between 1955 and 1966 and used for the production of hydrosulfuric acid for the leaching of the $\mathrm{Cu}$ that is contained in the chalcocite and covellite. Below the cementation zone, the primary mineralization is pyrrhotite-rich (up to $95 \mathrm{vol} \%$ ) and it forms an elongate subvertical lens $500 \mathrm{~m}$ deep, 40-70 $\mathrm{m}$ thick, and $1500 \mathrm{~m}$ long [21,59]. The ore resources are estimated to be $30 \mathrm{Mt}$ of pyrrhotite-dominated ore grading $0.7 \mathrm{wt} \% \mathrm{Cu}, 0.2 \mathrm{wt} \% \mathrm{Zn}$, and $0.1 \mathrm{wt} \% \mathrm{~Pb}$ (Table 1), from which $8 \mathrm{Mt}$ were extracted between 1964 and 1982, and were also used for producing hydrosulfuric acid. Problems that are related to pyrrhotite storage due to its fast oxidation, the low sulfur content (25 wt \%), the volume of mine wastes, and the corrosion of the iron infrastructure caused by the metallurgical method used at that time resulted in the closure of the mine in 1982 [60].

The Koudiat Aicha deposit was discovered in 1963 due to the presence of an airborne electromagnetic anomaly in an area with well-developed gossans. With $4.5 \mathrm{Mt}$ of ore grading $2.7 \mathrm{wt} \%$ $\mathrm{Zn}, 1 \mathrm{wt} \% \mathrm{~Pb}$, and $0.5 \mathrm{wt} \% \mathrm{Cu}$ in estimated resources, it represents the smallest of the deposits in the area. A similar magnetic anomaly that is associated with surface gossans is recognized along a ridge that extends ca. $2 \mathrm{~km}$ north to Laachach [61].

The Draa Sfar cluster contains two deposits: a southern one called Tazakourt and a northern deposit called Sidi M'Barek. At surface, the deposits are separated by the Tensift River, but there is no structural discontinuity between them [18]. The Tazakourt orebody consists of one $\mathrm{Zn}$-rich lens that 
extends N-S for $2 \mathrm{~km}$ and has been delineated between the -50 and $-1500 \mathrm{~m}$ levels, but it remains open at depth. It is the main ore lens at Draa Sfar and it has been exploited since the commencement of mining at the Draa Sfar district in 2004. The Zn-rich lens continues for more than $500 \mathrm{~m}$ north of the Tensift river into the Sidi M'barek deposit. The estimated resources of the Tazakourt Zn-rich ore body are $19 \mathrm{Mt}$ grading $5.28 \mathrm{wt} \% \mathrm{Zn}, 1.75 \mathrm{wt} \% \mathrm{~Pb}$, and $0.35 \mathrm{wt} \% \mathrm{Cu}$. In 2008, the Sidi M'Barek orebody had not yet been delineated and it was thought to be composed of a western or upper Zn-rich lens and an eastern or lower Cu-rich lens [18]. The commencement of mining in 2011 at the Sidi M'Barek deposit has resulted in increased accessibility to the deposit and its host rocks allowing for new data to be obtained from underground and surface mapping and from the drill core. The Sidi M'barek deposit is now known to include several other $\mathrm{Cu}$-rich lenses [62]. The estimated resources of the $\mathrm{Cu}$-rich lenses are $1 \mathrm{Mt}$ grading $0.2 \mathrm{wt} \% \mathrm{Zn}, 0.25 \mathrm{wt} \% \mathrm{~Pb}$, and $2 \mathrm{wt} \% \mathrm{Cu}$.

The Hajjar deposit is located in the Guemassa district, $30 \mathrm{~km}$ south of Marrakech. The deposit was discovered in 1968, owing to an electromagnetic anomaly that is delineated by airborne geophysical surveys. Ongoing mining of the Hajjar deposit since 1988 has produced over $20 \mathrm{Mt}$ of ore grading 8 wt \% Zn, 3 wt \% Pb, 0.5 wt \% Cu, and $25 \mathrm{~g} / \mathrm{t} \mathrm{Ag} \mathrm{[63].}$

To summarize, the past production and total resources of the massive sulphide deposits of the Moroccan Meseta are estimated to be more than $80 \mathrm{Mt}$ [64], with some deposits reaching a depth of $1500 \mathrm{~m}$. Most of these deposits have been classified as VMS deposits [18-23]. The dominance of pelitic rocks in the wall rock and the presence of felsic volcanic rocks in the Tazakourt orebody led Marcoux et al. [18] to classify the Draa Sfar deposit within the pelitic subgroup of the siliciclastic-felsic type of Franklin et al. [3]. In contrast, the presence of mafic intrusives led Lotfi et al. [27] to classify the Koudiat Aicha deposit as a mafic-siliciclastic (Besshi type) deposit. According to the geochemical classification of VMS deposits [54,65], the major massive sulphide deposits of the Moroccan Meseta belong either to the $\mathrm{Pb}-\mathrm{Zn}-\mathrm{Cu}$ type (Hajjar, Tazakourt, Koudiat Aicha) or the Cu-type (Kettara, Sidi $\mathrm{M}^{\prime}$ Barek; Figure $2 \mathrm{~b}$ ). In addition to the base metals, gold is being profitably recovered as a by-product in the Cu-rich lenses of the Sidi M'Barek deposit, which contain ca. 600-700 g/t Co and up to $0.5 \mathrm{~g} / \mathrm{t}$ Au. The Kettara ore contains up to $0.2 \mathrm{wt} \% \mathrm{Co}$ and $0.05 \mathrm{wt} \% \mathrm{Sn}, 0.8 \mathrm{~g} / \mathrm{t} \mathrm{Au}$ and 1 to $4 \mathrm{~g} / \mathrm{t} \mathrm{Ag} \mathrm{[66].}$ The $\mathrm{Cu}$-rich deposits are also characterized by the higher contents of $\mathrm{Bi}$ and Se than the Zn-rich deposits. Traces of Bi and Se-bearing minerals have been described in the Kettara ore [66], while native bismuth and Bi-rich sulphides and selenides are abundant as individual grains or complex intergrowths in the Cu-rich lenses of Sidi M'Barek. Finally, the location in a "compressional jog" of a regional shear zone and the absence of volcanic rocks in the Kettara region led N'diaye et al. [17] to propose a genetic model in which the Kettara deposit was formed by syn-metamorphic fluid migration through shear zones.

\subsection{Regional Distribution of the Deposits}

The Central Jebilet unit, and its southern extension, the Guemassa massif (Figures 1c and 2) host the MMSD. The Central Jebilet is a triangular crustal block that is delimited by the West Moroccan Shear Zone to the west and the Marrakech Shear Zone to the east (Figure 2a). The West Moroccan Shear Zone (WMSZ) extends from Tichka in the South to Rabat in the North, and it was active during both the sedimentation and the overprinted regional metamorphism [34,67]. The Marrakech Shear Zone (MSZ) separates the Sarhlef schists of Central Jebilet from the Kharrouba flysch of Eastern Jebilet, suggesting that it was also active during those times [49]. Central Jebilet is also characterized by the presence of numerous mafic and felsic intrusions that form a bimodal magmatic association $[16,51,68]$, as well as two granodioritic plutons that are spatially associated with the MSZ. The spatial association of the massive sulphide deposits with bimodal magmatism indicates that this triangular crustal block corresponds to a high-temperature thermal corridor that is located at the intersection between two major crustal fractures. 
At the map-scale, the massive sulphide deposits of Central Jebilet, their gossans, and the related magnetic anomalies are arranged into N-S to NNE-SSW subvertical lineaments $[21,26,69]$ (Figure 2a). These lineaments include:

(1) The Koudiat Aicha deposit, together with the Bouhane and Laachach deposits and gossans form the western lineament, which is offset by the Mesret dextral fault (Figure 2a). This lineament is located some $1.5 \mathrm{~km}$ to the east of a parallel ridge that is formed by the Koudiat Bouzlaf, Koudiat Hamra, and Koudiat Diab microgranitic intrusions [26] (Figure 3). Our structural and microstructural observations indicate that the gossans are located within a ductile shear zone, which is approximately $40 \mathrm{~m}$ wide, where the metasedimentary rocks have a very intense planar, phyllonitic to mylonitic, steeply dipping fabric, which strikes roughly north-south.

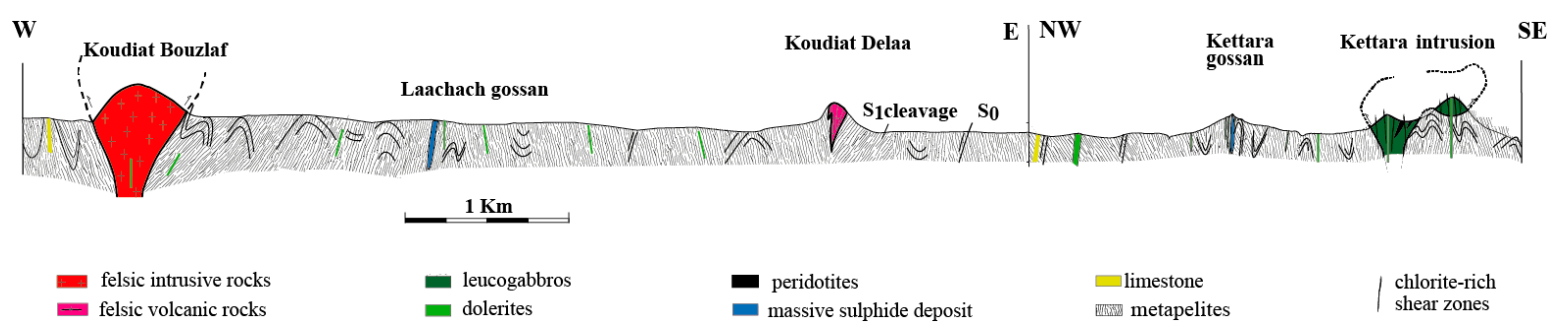

Figure 3. Cross-section through the western and central massive sulphide lineaments (see location in Figure 2a).

(2) The Kettara deposit belongs to a central lineament that includes the Benslimane and Kerkoz deposits and the associated gossans. The Kettara deposit is located $\sim 1 \mathrm{~km}$ northwest of the mafic-ultramafic Kettara intrusion, which is part of a suite of mafic intrusions that lie broadly parallel to the massive sulphide lineament. This lineament is located within a through-going N-S sinistral shear zone that is interconnected by a short ENE dextral shear zone in the Kettara area [17,70]. The Benslimane and Kerkoz deposits occur at the south-eastern extension of the Kettara deposit, 1 km west of the felsic side of the composite Ouled Har intrusion. A ridge that is formed by the Koudiat Delaa felsic volcanic and volcaniclastic rocks separates the western and central sulphide lineaments (Figures 2a and 3).

(3) The Draa Sfar district belongs to an eastern ore lineament that includes Nzalet el Harmel and Safsafat gossans. The southern part of Draa Sfar (Tazakourt orebody) is located near the felsic volcanic and volcaniclastic rocks of Koudiat Tazakourt, while its northern part (Sidi M'Barek deposit) is located near the felsic intrusion of Draa El Harach. To the south of Kettara, an array of gossans and gabbroic intrusions, including the Koudiat Arhil intrusion, separates this lineament from the central lineament [69].

To summarize, there is evidence for a N-S to NE-SW structural control, as shown at the regional scale by the distribution of the massive sulphides along lineaments as well as by the arrays of magmatic bodies with a similar trend. These lineaments correspond to shear zones [26,35], which likely played an important role in the control of the geometry of the mineralization. It is worth noting that this suite of shear zones trends at a low angle to the WMSZ, which represents the western boundary of the Devono-Carboniferous basins in the Moroccan Meseta [34,67]. These shear zones may represent faults that were originally active during sedimentation and subsequently reactivated during compressional tectonics. In the case of the Tazakourt $\mathrm{Pb}-\mathrm{Zn}$ deposit, it has been suggested that synvolcanic/sedimentary faults that are directly related to massive sulphide deposition might have controlled the Draa Sfar basin [19]. In the case of the Kettara Cu-deposit, it has been shown that mineralization is located in a compressional jog that is located between two "en echelon" shear zones [17]. In the Guemassa massif, the Hajjar deposit is located within a transpressive shear zone [24]. We conclude that the studied deposits of Central Jebilet are located within different structural lineaments that are separated by magmatic ridges that could represent small-scale N-S to NE-SW troughs or sub-basins. 


\subsection{Morphology}

The majority of the massive sulphides of the Central Jebilet have lens-type morphology and they lack well-developed stockwork zones. These lenses are generally subvertical and parallel to the regional cleavage (Figure 3). Notably, field studies in the area shows that most of the massive sulphides occur in sub-vertical shear zones, where the host rocks show intense planar foliations and lineations [71].

In the Koudiat Aicha deposit, the massive to semi-massive pyrrhotite-rich lenses are hosted by metapelites. Our recent mapping shows that the location of the deposit is marked at the surface by a ridge of dark-brown weathered rocks with a very intense, steeply-dipping foliation and a moderately-plunging lineation. This ridge, which represents a major shear zone, extends northwards to the smaller Laachach sulphide deposit, and the Mesret Fault offsets it. The sulphide mineralization within this shear zone forms subvertical lenses trending N-S parallel to the intense foliation. The mineralized lenses extend from surface to at least $500 \mathrm{~m}$ deep and their thickness varies from few meters to $25 \mathrm{~m}$. A stockwork-type mineralization is absent, but disseminated sulphides become abundant near the sulphide lenses [26].

In the Kettara deposit, the massive sulphides form an elongated sub-vertical, pyrrhotite-dominated massive sulphide lens, which is approximately $1.5 \mathrm{~km}$ long, $500 \mathrm{~m}$ deep, and 40 to $70 \mathrm{~m}$ thick, situated within a shear zone parallel to the NE-SW regional structural trend $[17,21]$. The orebody is hosted by metapelitic rocks (Figure 3). In the cross-section, the deposit seems to cut across the bedding $\left(\mathrm{S}_{0}\right)[17,72]$. The foliation becomes conformable to the deposit boundaries, dipping to the north in the southern side of the deposit, and to the south in the northern side of the deposit.

In the Draa Sfar district, the Zn-rich lens strikes N-S, dips steeply eastwards, and then extends horizontally for $\sim 2 \mathrm{~km}$. The orebody has been delineated between $-50 \mathrm{~m}$ and $-1500 \mathrm{~m}$ levels and it remains open at depth. Its thickness varies between 0.2 and $30 \mathrm{~m}$. Such thickness variations, both occurring horizontally and vertically, have been related to topographic variations within the basin and subsequent deformation [19]. The Zn-rich lens forming the Tazakourt orebody includes felsic volcanic and volcaniclastic rocks in its footwall and metapelitic rocks in the hangingwall. At the Sidi M'barek deposit, metapelites host the $\mathrm{Zn}$-rich lens and the $\mathrm{Cu}$-rich lenses. Here, the $\mathrm{Cu}$-rich massive sulphides form several N-S to NNE-SSW small lenses ( $<150 \mathrm{~m}$ long and $<10 \mathrm{~m}$-thick), the number of which increases northwards, from one principal lens in the southern part to several lenses in the northern part of the deposit.

In the Hajjar deposit that is located in the Guemassa massif, the sulphide mineralization is underlain by felsic volcanic and volcaniclastic rocks, and the hangingwall includes metapelitic rocks that are interbedded with sandstone and carbonates. The deposit is located within a regional brittle-ductile transpressive shear zone trending NW-SE [24]. The massive sulphides form three major steeply dipping lenses, up to $120 \mathrm{~m}$-thick, which are intercalated with metapelites and sandstones. The lenses are elongated within the $S_{0-1}$ foliation and they display thickening within the fold hinge zones [24]. Well-developed chalcopyrite-rich quartz-sulphide veins within the footwall sequence have been interpreted as a stockwork or stringer zone [22,73]. A high-temperature hydrothermal zonation with a central quartz zone surrounded by sericite, biotite, and chlorite peripheral zones characterize this zone [22]. ${ }^{40} \mathrm{Ar} /{ }^{39} \mathrm{Ar}$ ages of $300.9 \pm 2.6 \mathrm{Ma}$ on biotite [74] indicate that the stockwork postdates the VMS mineralization. Moreover, the occurrence of andalusite and cordierite in the Hajjar country rocks suggests that this age records a HT-LP contact metamorphism that is related to intrusion of a later leucogranite [24].

To sum up, the massive sulphide bodies form sub-vertical lenses that are elongated along the regional cleavage and are typically located along shear zones that are recognizable by the presence of intense foliation and lineation, as well as tight folding [17,24]. Well-developed stockwork-stringer zones marking the pathways for hydrothermal fluid upwelling are absent. However, disseminated sulphides are abundant near the sulphide lenses but the host black shale is devoid of unequivocal textural or structural features that are indicative of sedimentary or diagenetic sulphides [75], with the 
exception of the presumably diagenetic nodular pyrrhotite and minor chalcopyrite, as reported from the footwall shales in Draa Sfar deposit [18,19]. It is clear that, whatever the primary origin of the VMS deposits in the Jebilet massif, they have been substantially deformed and remobilized into a series of shear zone-hosted lenses.

\subsection{Mineralogy, Ore Types and Zonation}

A conspicuous feature of the massive sulphides of the Moroccan Meseta is the dominance of pyrrhotite and the absence of sulphate minerals (barite, gypsum). Monoclinic, as well as hexagonal pyrrhotite, has been described [26,63,74,76]. Other major minerals include sphalerite, galena, chalcopyrite, arsenopyrite, tetrahedrite, and pyrite. Magnetite, stannite, cassiterite, cobaltite, electrum, native $\mathrm{Bi}$, and Bi-sulphosalts are the most common of the minor phases $[18,22,66,73,77]$. The relative abundance of sphalerite (up to $10 \mathrm{vol} \%$ ) and galena (up to 5 vol \%) characterize the Zn-rich deposits (Hajjar, Draa Sfar South, Koudiat Aicha), while chalcopyrite is more abundant in the $\mathrm{Cu}$-rich deposits (up to $30 \mathrm{vol} \%$ ). The latter are also rich in cobaltite, electrum, and Bi-sulphosalts. Associated minerals include chlorite, quartz, sericite, carbonates, and ilmenite $+/-$ talc.

The massive sulphides are generally fine-grained and they show different types of structures, including massive or semi-massive ore, banded ore, pyritic ore, and cupriferous ore. In all of the deposits, the massive ore is mainly composed of pyrrhotite with low amounts ( $<10 \mathrm{vol} \%)$ of wall rock fragments, the proportion of which increases to ca. 50\% in the semi-massive ore. In the Kettara orebody, the massive ore comprises pyrrhotite (70-90 vol \%), chalcopyrite (5-25 vol \%), magnetite (3-5 vol \%), sphalerite ( $2 \mathrm{vol} \%)$, arsenopyrite ( $<1 \mathrm{vol} \%)$, and traces of galena and native bismuth [17]. They are accompanied by quartz and chlorite, which are locally associated with talc and mica, or they enclose phosphate minerals and Ti-oxides. Pyrrhotite and wall rocks are oriented parallel to the $\mathrm{S}_{1}$-foliation and the pyrrhotite has typically been deformed and elongated along the cleavage plane. Some magnetite porphyroblasts show foliation deflection and they contain pyrrhotite inclusions defining an internal foliation that follows the external foliation. The fine-grain size and straight orientation of the inclusions allow for their recognition as a $S_{1}$-foliation formed during the early stages of deformation [78,79]. Frequently, there is a progressive gradation from semi-massive ore at the margins of the deposits to massive ore in the core $[16,17]$. These structures have been interpreted as resulting from replacement of the host rocks by the mineralizing fluid [20,80-82]. Centimeter to meter-scale shear zones have developed local mylonite zones within the massive pyrrhotite. The presence of recrystallized grains of pyrrhotite showing annealing textures with $120^{\circ}$ triple junctions characterize these mylonite zones.

Some deposits contain banded ore, which shows the alternation of sulphide layers that have different compositions. The most abundant is a faint thin layering marked by the alternation of sphalerite-rich bands and pyrrhotite-rich bands (Figure $4 \mathrm{~b}, \mathrm{e}$ ). This banded ore is typical of the $\mathrm{Zn}$-rich deposits and well-developed tectono-metamorphic fabrics characterize it (Figure 4a). The banded ore displays mesoscale chaotic textures that are similar to the "Durchbewegungs textures" described in the deformed Scandinavian ore deposits [83]. Locally, the banded ore displays a mylonitic texture that is marked by highly elongated pyrrhotite grains with the development of $C$ and $C^{\prime}$ shear planes and pressure shadows around arsenopyrite and sphalerite grains. Grain flattening and elongation characterize galena, while chalcopyrite crystallizes in the pressure shadows. These features have been interpreted to result from fluid-state remobilization $[12,84]$. They indicate that these sulphide minerals are deformed and are most likely their crystallization is pretectonic to syntectonic. A rhythmically banded semi-massive ore, which is characterized by mm-scale alternation of pyrrhotite-rich bands with chlorite and sericite-rich layers, is locally developed at the extremities of the mineralized lenses of Draa Sfar (Figure 4d). Such structures may represent a primary depositional feature, but the fact that these bands are strictly parallel to the cleavage fabric and developed in high strain zones is likely to be due to the remobilization of pyrrhotite during deformation and metamorphism [85]. Similarly, a rhythmically banded ore that is composed of alternating pyrrhotite-rich and volcanic sandstones is present in the footwall and the hanging wall of the Hajjar deposit, and it may represent a primary depositional feature 
that was accentuated by pyrrhotite remobilization during deformation and metamorphism [23,24]. No pristine sedimentary structures have been observed, indicating that this banding most likely results from the replacement of favorable sedimentary layers by sulphides.
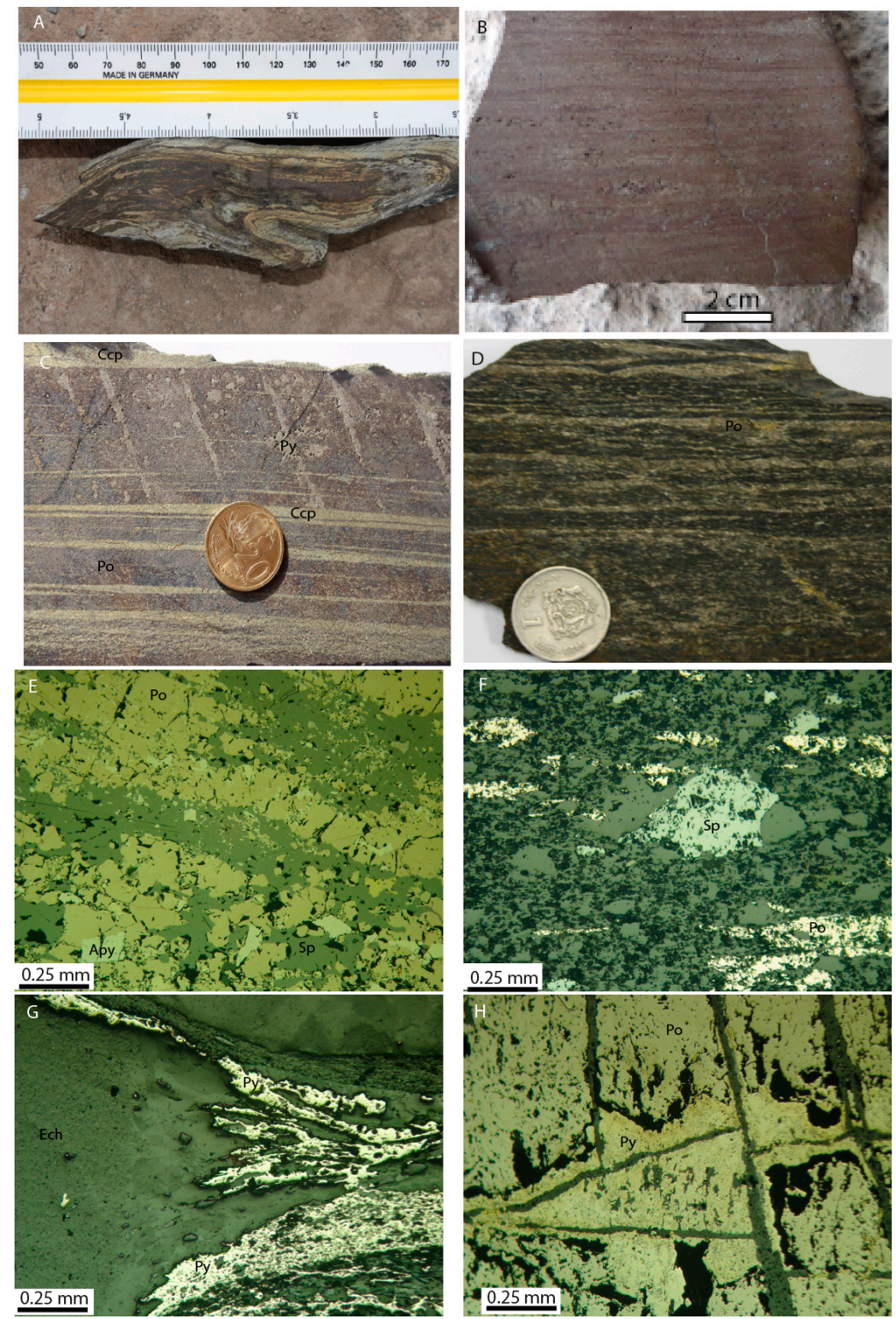

Figure 4. Representative photographs of some types and textural features of the Moroccan massive sulphide deposits (MMSD). (A) $\mathrm{P}_{2}$ fold developed in a semi-massive pyrrhotite (Zn-rich lens of Tazakourt, Draa Sfar South deposit); (B) Faint layering marked by alternating sphalerite-rich and pyrrhotite-rich bands in the Zn-rich lens of Tazakourt; (C) Pyrite (Py) infilling cross-cutting and replacing pyrrhotite (Po); the pyrite veins are in turn replaced by chalcopyrite (Ccp) in parallel bands; (D) semi-massive ore with pyrrhotite-rich bands alternating with chlorite and sericite-rich bands. Rock located at the extremity of one Cu-rich lens of the Sidi M'barek orebody; photos (E-H) are microphotographs with plane polarised reflected light (E) Banded ore with sphalerite (Sp, grey)- and pyrrhotite (Po, pale yellow)-rich bands and disseminated arsenopyrite (Apy) grains (white) (crossed nichols); (F) Pyrrhotite (Po) grains elongated along the foliation plane showing pressure fringes around sphalerite (Sp) in a silicate-rich matrix (crossed nichols); (G) Pyrite (Py) in pressure shadows around Echinoderm (Ech) clasts (crossed nichols); and, (H) fractures infilled with carbonates and pyrite replacing pyrrhotite (crossed nichols). 
Pyritic ore results from the hydrothermal replacement of massive pyrrhotite by pyrite and it has been described in all deposits; it is well developed in the Cu-rich lenses of Sidi M'barek, at Laachach and in the Kettara deposit. Although some pyrite could be primary in the Hajjar deposit [22], most of the pyrite in the MMSD is secondary (Figure 4e). Pyritic ore occurs as cm- to meter-scale veins or as pods cross-cutting the semi-massive to massive pyrrhotite and the host schists (Figure 4c). At Kettara, the pyritic ore is commonly brecciated and composed of centimeter-scale brecciated pyrite cubes, together with rare marcasite and chalcopyrite that are associated with carbonates [17]. Here, the pyritic ore has been affected by brittle to semi-brittle deformation [86], but it is clearly unaffected by ductile deformation. Pyrite crystals are locally fractured and brecciated, but they typically overgrow the main foliation and lack the features that are associated with ductile deformation, such as pressure shadows. In the Cu-lenses of Sidi M'Barek, pyrrhotite is crosscut and then replaced by pyrite veins (Figure 4h). Pyrite also occurs as disseminated minerals in the host rocks surrounding the Cu-deposits. In the hanging wall of the Kettara ore lens, pyrite occurs as euhedral crystals, while in the carbonaceous beds of Sidi M'Barek, pyrite crystallizes in the pressure shadows around echinoderm clasts or as flattened crystals along the cleavage plane (Figure $4 \mathrm{~g}$ ). These microstructural relationships indicate that the pyritic ore is contemporaneous or post-dates the main period of ductile deformation in the Kettara and Sidi M'barek deposits [11].

The cupriferous ore is well developed in the Cu-rich lenses of Sidi M'Barek, where it forms $\mathrm{cm}$-scale parallel veins and fractures of chalcopyrite cutting and replacing both massive pyrrhotite and pyritic ores (Figure 4c). This "banded" ore that is composed of chalcopyrite-rich bands alternating with pyrrhotite- and/or pyrite-rich bands is spatially associated with brittle-ductile fractures, and it most likely results from the remobilization of chalcopyrite. Cupriferous ore resulting from hydrothermal replacement of pyrrhotite by chalcopyrite is also described in the Hajjar deposit at the transition between the chalcopyrite-rich "stockwork" zone and the massive pyrrhotite [22].

Zoning in the sulphide lenses is absent or is poorly known. Study of a mineralized lens of the Koudiat Aicha deposit shows that $\mathrm{Cu}, \mathrm{Au}, \mathrm{Ag}, \mathrm{Zn}$, and $\mathrm{Pb}$ are enriched in the upper ore zone, and $\mathrm{Cu}$ in the footwall, suggesting a relict stringer zone [27]. Marcoux et al. [18] have proposed that the Cu-rich lens of Sidi M'Barek may represent a stockwork zone of the main Zn-rich sulphide lens at Draa Sfar. Ongoing drilling and exploration have permitted the recognition of a dozen $\mathrm{Cu}$ lenses, which extend to the North of the Zn-rich lens [62]. Such a "zoning" is dissimilar to that commonly found in other VMS deposits, with $\mathrm{Cu}$-rich zones towards the central and lower parts of the masses, barren pyrite in the core, and a $\mathrm{Zn}+\mathrm{Pb}$ enrichment towards the upper and lateral zones of the orebodies, e.g., [54,87-90].

To summarize, there are three stages of sulphide mineralization in the MMSD (Figure 5) (i) a pretectonic to syntectonic stage related to the precipitation of massive pyrrhotite, together with small amounts of chalcopyrite, sphalerite, and galena. The development of pressure shadows around competent sulphides (sphalerite, arsenopyrite) indicates evidence for pretectonic sulphides; (ii) a syn-tectonic to late tectonic pyrite-dominated stage during which pyrite replaced the earlier pyrrhotite; and, (iii) a localized late to post-tectonic $\mathrm{Cu}$-rich stage during which chalcopyrite was remobilized along brittle to semi-brittle fractures. 


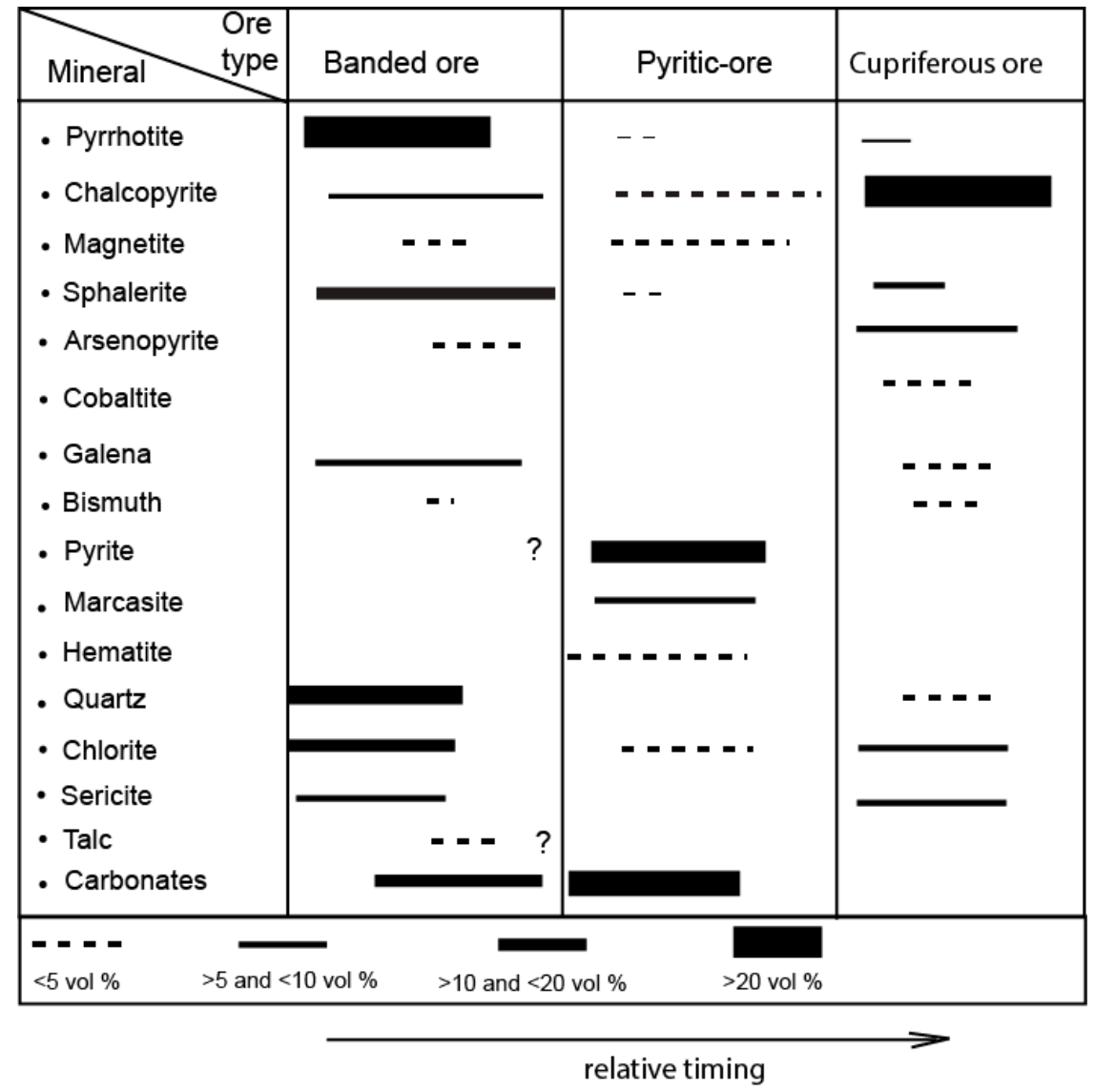

Figure 5. Paragenetic evolution of the main phases of mineralization in the MMSD.

\subsection{Relationships with the Country Rocks}

The Devono-Carboniferous basin of the Western Meseta includes the Central and Eastern Jebilet sub-basins in which the Sarhlef schists and the Kharrouba Flysch were respectively deposited. Beauchamp et al. [49] interpreted the Sarhlef Schists to have been deposited in an anoxic shallow water environment and the Kharrouba flysch in a deep trough. Independent evidence for shallow marine conditions that are above the storm wave base level for the Sarhlef Schists is found in the Draa Sfar deposit, where within the metapelites there are layers of limestone that are composed of crinoid-dominated debris displaying a packstone texture and indicating deposition within an agitated environment located at the zone of wave action, approximately between 5 and $20 \mathrm{~m}$ deep [91]. Similar Visean basins are described as transtensional pull-apart basins in the northern part of the Meseta, in the Central Massif, where it is known as the Sidi Bettache Basin [36,37,47], but the structural peculiarity of the Central Jebilet basin is its location at the intersection of two major crustal fractures. In central Morocco, Carboniferous syntectonic flysch, similar to those of Eastern Jebilet, were deposited in a compressional foreland basin [92].

The MMSD do not appear to be associated with a particular stratigraphic level of the Sarhlef schists $[25,51]$. The massive sulphides occur either within strongly deformed schists (Kettara, Koudiat Aicha, Sidi M'Barek in Draa Sfar) or at the contact between the schists and felsic volcanic and volcaniclastic rocks (Hajjar, Tazakourt in Draa Sfar) $[19,22,26,73,85]$. South of Koudiat Aicha, limestone beds within the schists have been described as the upper part of the Sarhlef Schists [26]. However, these limestones are strongly folded by tight northward-plunging folds and their relationship to the massive sulphides is not clear. The schists are considered to have a black shale protolith, which has been advocated to explain the predominance of pyrrhotite over pyrite. The mineralizing fluid would have been reduced due to its interaction with organic-matter [17-20,23,27]. 
The bimodal magmatism, which includes ca. one-third of felsic rocks and two-thirds of mafic rocks, is of particular interest because of its spatial association with the massive sulphides. The earliest event includes relatively scarce felsic-dominated volcanic rocks that form highly deformed rhyolitic to rhyodacitic domes and related volcaniclastic rocks $[19,22,51,52,77]$. The absence of contact metamorphic aureoles around these bodies indicates rapid cooling. Moreover, the occurrence of peperitic textures in the margins of rhyodacitic domes in the Hajjar deposit indicates intrusion within still wet and unconsolidated sediments $[93,94]$. However, the most volumetrically important magmatism is intrusive and it forms layered mafic-ultramafic intrusions, doleritic dykes, microgranitic intrusions, and granodioritic plutons. The contacts of the intrusions with the host rocks are sharp, with a metamorphic aureole of "spotted" schists containing andalusite and cordierite. These spots post-date the initial D1 deformation, but they are deformed by D2, indicating emplacement toward the end of D1 $[30,68,95]$.

The mafic-ultramafic rocks include peridotites, gabbros, leucogabbros, and dolerites [51-53]. The majority of these rocks have clearly formed by cumulate processes, producing igneous layering. Some mafic rocks are however found in dykes that cut across both the intrusions and the country rocks, and they are more likely to represent magmatic compositions. The mafic-ultramafic rocks show a Fe-enriched trend [52] and have lower $\mathrm{Nb} / \mathrm{Y}(<0.67)$ than alkaline basalts. In the $\mathrm{TiO}_{2}$ versus $\mathrm{Zr} / \mathrm{P}_{2} \mathrm{O}_{5}$ diagram of [96], the non-cumulate mafic rocks plot in the tholeiitic field (Figure 6a), which is consistent with the $\mathrm{Nb} / \mathrm{Y}$ ratios and the Fe-enrichment.
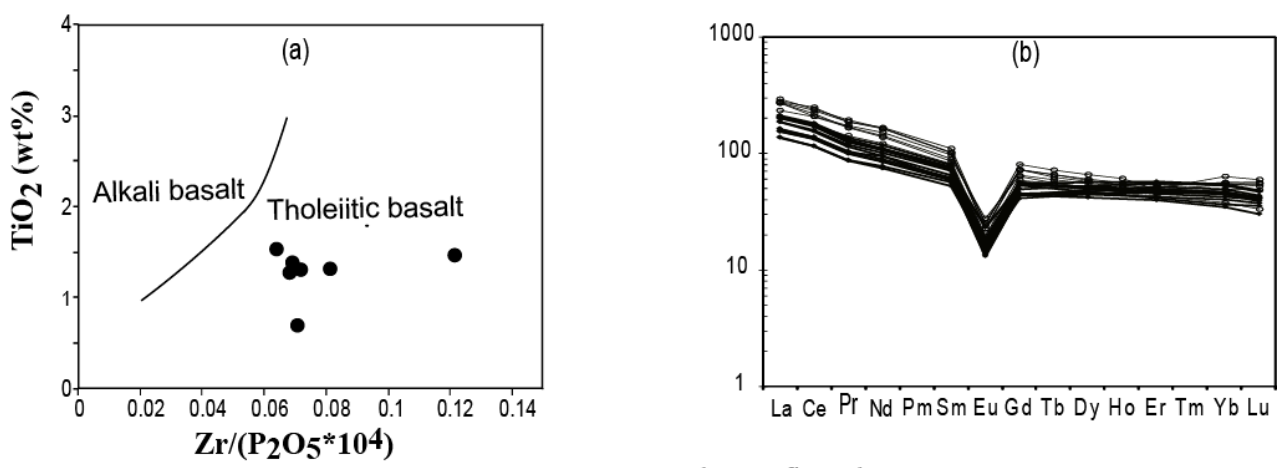

- non cumulate mafic rocks o microgranites and quartz-diorites - Draa Sfar rhyodacites
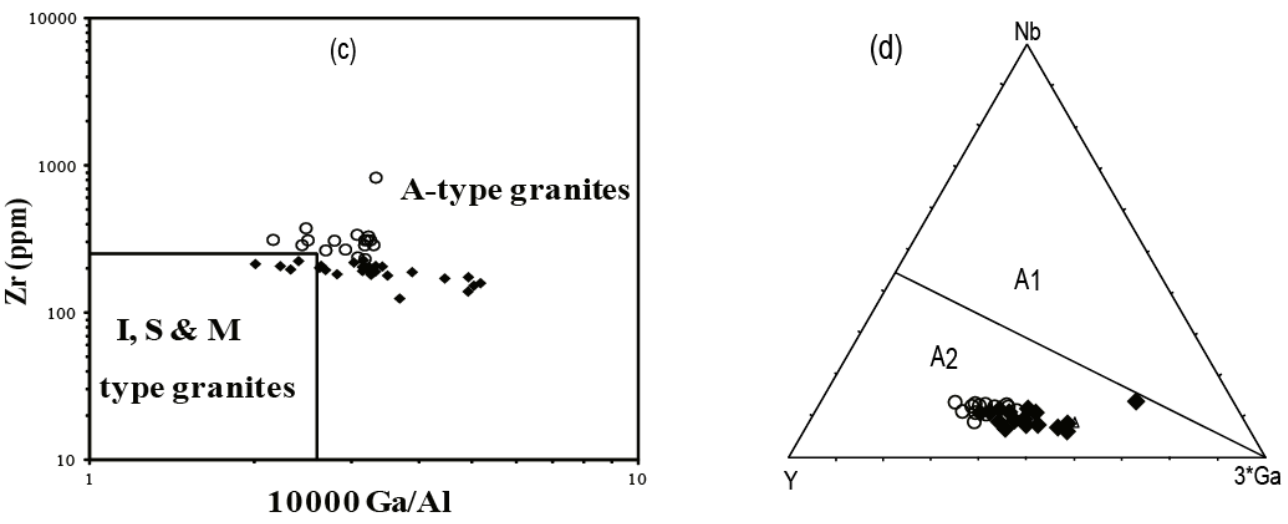

Figure 6. (a) Plot of $\mathrm{TiO}_{2}$ versus $\mathrm{Zr} / \mathrm{P}_{2} \mathrm{O}_{5}$ for non-cumulate mafic rocks of the Jebilet bimodal intrusive rocks. The fields of alkali and tholeiitic basalts are from [96]; (b) Chondrite-normalized REE plot for the felsic volcanic and intrusive rocks of the bimodal association of Central Jebilet. Normalizing values are from Sun and McDonough [97]; (c) Jebilet microgranites and rhyodacites in the Zr versus $10000 \mathrm{Ga} / \mathrm{Al}$ diagram of Whalen et al. [98], showing affiliation with A-type granites; and (d) Jebilet felsic microgranites and rhyodacites in the $\mathrm{Nb}-\mathrm{Y}-\mathrm{Ga}$ ternary diagram for the subdivision into $\mathrm{A}_{1}$ and $\mathrm{A}_{2}$-type granites [99]. Data are from [19,53]. 
According to criteria that were proposed by several authors, e.g., [98,99], the microgranites display geological and geochemical features that are characteristic of A type granites: (1) they were intruded to very high levels in the crust, as indicated by granophyric intergrowths along with comagmatic subvolcanics emplaced at the same structural level; (2) they contain interstitial Fe and Cl-rich biotite, hastingsite, and fluorite; (3) their Mg and Ca contents are low and their REE (except Eu) and HFSE contents are high (Figure 6b); and, (4) they have high magmatic temperatures (up to $900{ }^{\circ} \mathrm{C}$ [53]) and their $\mathrm{Fe} / \mathrm{Mg}$ and $\mathrm{Ga} / \mathrm{Al}$ ratios are high (Figure $6 \mathrm{c}$ ). High $\mathrm{Rb} / \mathrm{Nb}$ and $\mathrm{Y} / \mathrm{Nb}$ ratios (Figure $6 \mathrm{~d}$ ) further indicate that these granites belong to the $\mathrm{A} 2$ type of granites [99].

The Jebilet felsic volcanic rocks share characteristics of alkaline geochemistry with the nearby felsic intrusives and they correspond to the $\mathrm{A}_{2}$-type of rhyolites (Figure 6). Like the microgranites, the felsic volcanic rocks were likely produced at depths of $15 \mathrm{~km}$ or less by high-temperature melting $\left(\mathrm{ca} .900{ }^{\circ} \mathrm{C}\right)$ of a tonalitic source [53]. The felsic volcanics have geochemical and isotopic compositions similar to those of felsic rocks that are associated with VMS deposits within felsic-dominated environments [100-104]. The host sequence, which is dominated by siliciclastic rocks that are deposited in a continental margin basin, is consistent with the "siliciclastic" class of VMS deposits defined by Franklin et al. [3].

Specific associations of petrologic suites of mafic and felsic rocks are present in specific VMS deposit environments, e.g., [103]. The bimodal magmatic association of Central Jebilet is composed of $\mathrm{A}_{2}$-type alkaline felsic rocks and tholeiitic mafic rocks, which include both MORB-like and destructive plate-margin like basaltic compositions [53,105]. One possible equivalent of the bimodal association of Central Jebilet is the bimodal basalt-subalkaline/peralkaline rhyolite province of the Southern British Caledonides, which is also associated with polymetallic sulphide mineralization [106,107]. $\mathrm{Cu}$-rich massive sulphide deposits seem to be associated to mafic intrusions and $\mathrm{Pb}-\mathrm{Zn}$ deposits to felsic intrusions [25], suggesting that the hydrothermal systems of the Central Jebilet had a direct relationship with magmatism.

\section{Hydrothermal Alteration}

Hydrothermal alteration is widespread at both the regional scale, since most of the intrusions are hydrothermally altered, and at a local scale, since there is a strong hydrothermal alteration that is associated with the ore deposits.

Regionally, a pervasive hydrothermal alteration that is centered on the intrusions resulted in widespread hydrothermal alteration of the igneous rocks and a retrogression of the contact metamorphic minerals into secondary hydrated minerals, while more focused fluid flow operated along zones of active deformation that transformed the igneous rocks into HT-mylonites and ultramylonites [30,70,95].

In the mafic intrusions, primary minerals (olivine, plagioclase, clinopyroxene) were partially or totally altered into $\mathrm{Ca}$-amphibole, $\mathrm{Mg}$-chlorite, and $\mathrm{Ca}-\mathrm{Al}$ silicates (epidote, prehnite, and muscovite) in undeformed zones, while focused fluid flow in zones of active deformation (centimeter-scale shear zones) was associated with the transformation of gabbros into ultramylonites with the insoluble primary minerals (ilmenite, spinel, apatite) being the only to persist in a Ca-amphibole-rich matrix [70]. After the thermal re-equilibration of the intrusions, alteration and focused fluid flow led to the formation of chlorite-rich shear zones and associated quartz \pm calcite veins (Figure 7a). The resulting alteration pattern is a sericite alteration zone in the selvages of the shear zones and a Fe-rich chlorite alteration zone in the inner parts [70]. Chlorite geothermometry indicates temperatures of 275 to $350{ }^{\circ} \mathrm{C}$ in the undeformed gabbros and 345 to $430{ }^{\circ} \mathrm{C}$ in the shear zones. The higher temperature that is indicated for chlorite in the shear zones is consistent with heat advection related to large fluid fluxes within the shear zones [108]. 


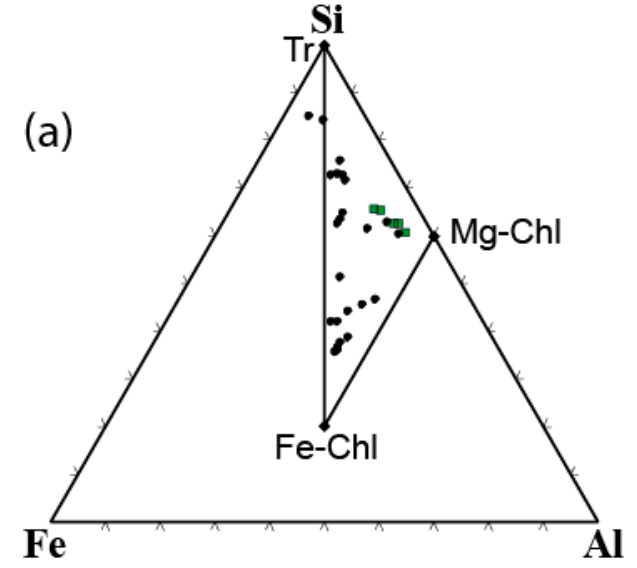

- shear zones

- mafic-ultramafic protoliths

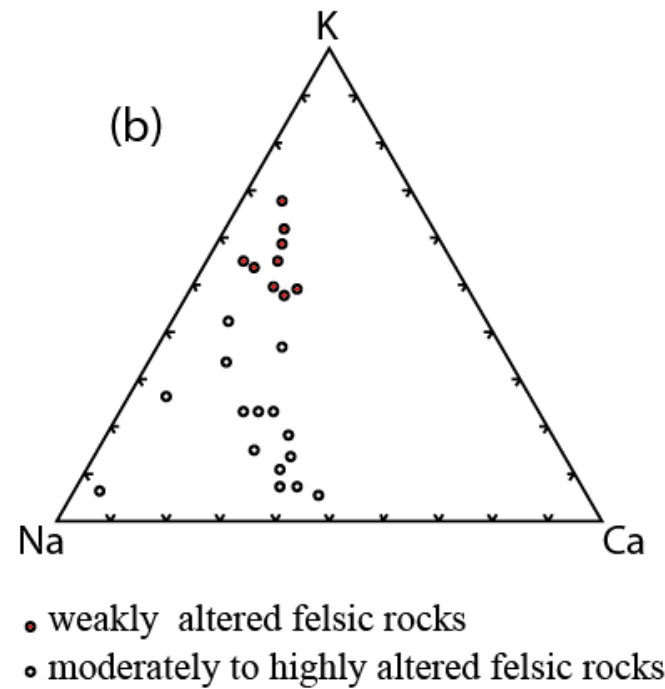

Figure 7. (a) Projection of the Kettara shear zones in $\mathrm{Si}, \mathrm{Fe}$, and $\mathrm{Al}$ ternary diagram (cation proportions). The whole rock composition of the Kettara shear zones evolves toward the Fe-chlorite-tremolite ( $\mathrm{Tr}$ ) join; and (b) Ternary K-Na-Ca diagram (cation proportions) showing enrichment in $\mathrm{Na} \pm \mathrm{Ca}$ in the altered felsic rocks; modified from [70,109].

In the felsic intrusions the commonest metasomatic alterations are albitization, chloritization, and sericitization. A pervasive alteration, combined with homogeneous deformation, transformed the innermost parts of the granitic bodies into trondhjemitic and tonalitic gneisses, while focused fluid flow led to the formation of gneiss-schists in LT shear zones at the contact with the wall rocks [109]. Mass transfer estimates show that this regional hydrothermal alteration was accompanied by exchange reactions of $\mathrm{K}$ and $\mathrm{Na}+\mathrm{Ca}$ (Figure $\mathrm{7b}$ ) and by the leaching of metals from the felsic intrusions, which has been suggested to play an important role in the genesis of the massive sulphide deposits of the Jebilet massif $[25,68]$.

Ore-related hydrothermal alteration is characterized by chloritization, sericitization, silicification, and carbonatization. In the Hajjar deposit, chloritization is dominant in the footwall and within the mineralized lenses, while sericitization is more pronounced in the hanging wall [22,73]. In the Hajjar deposit, chlorite is Mg-rich in massive sulphide lenses and Fe-rich in the chalcopyrite-rich vein system and the unmineralized zones of the footwall sequence [22]. The $\mathrm{XFe}\left(=\mathrm{Fe}_{\text {total }} /\left(\mathrm{Fe}_{\text {total }}+\mathrm{Mg}\right)\right.$ ratios increase with the increasing distance from the sulphide ores. They vary from $\sim 0.2-0.3$ in the banded ore to $\sim 0.4-0.5$ in the immediate footwall, and to $\sim 0.7-0.8$ in the unmineralized volcanic rocks of the footwall $[73,110]$. Chlorite geothermometry indicates temperatures between 240 and $360{ }^{\circ} \mathrm{C}$ for the chlorite that is associated with sulphides $[22,73,110]$.

In the Draa Sfar cluster, hydrothermal alteration is characterized by sericite alteration in both the footwall and the hanging wall of the Sidi M'Barek deposit, while the Zn-rich lens of the Tazakourt orebody is characterized by a footwall chlorite alteration and a hanging wall sericite alteration $[19,20]$. Mass transfer estimates indicate that chloritization is accompanied by enrichment in Fe and $\mathrm{Mg}$ and a loss in $\mathrm{Na}$ and $\mathrm{K}$ [19]. The XFe ratio of chlorite ranges from 0.3 to 0.95 , increasing away from the $\mathrm{Zn}$-rich mineralized lens. The higher $\mathrm{Mg}$ content of chlorite within chloritized inclusions in the massive sulphide and in the footwall alteration zone is indicative of intense Mg-metasomatism that accompanied sulphide deposition [19]. Chlorite geothermometry indicates temperatures of 376 to $388^{\circ} \mathrm{C}$ for Fe-rich chlorite in the less altered country rocks, 322 to $375{ }^{\circ} \mathrm{C}$ in the altered footwall, and 276 to $346{ }^{\circ} \mathrm{C}$ inside the mineralized lens. These temperatures are inconsistent with a primary hydrothermal temperature regime in which temperature is expected to be higher in the highly altered zones than in the least altered ones [111]. Such a pattern has been observed in few deposits and interpreted as related to seawater entrainment into the feeder zone [54]. 
In the Kettara Cu-deposit, although hydrothermal alteration is more pronounced in the footwall than in the hanging wall, both of them are characterized by the dominance of chlorite near the mineralized lens and sericite-alteration further away [17,73]. Mass transfer estimates indicate that chloritization was accompanied by leaching of Si and Ca, which subsequently crystallized as quartz-calcite veins within the wall rocks of the ore body [21]. More importantly, the alteration pattern that was observed in the Kettara deposit is similar to the alteration pattern that is associated to the shear zones in the Kettara intrusion [17,25]. Chlorite geothermometry indicates temperatures of 320 to $375{ }^{\circ} \mathrm{C}$ for hydrothermal chlorite and 347 to $370{ }^{\circ} \mathrm{C}$ for chlorite that is associated with the massive pyrrhotite [17].

In the Koudiat Aicha Zn-rich deposit, the alteration extends into both the hanging wall and footwall, with an increase in Mg-chlorite in the footwall and sericite in the hanging wall. Mass transfer estimates indicate that footwall alteration is accompanied by enrichments in $\mathrm{Fe}, \mathrm{Mn}$, and $\mathrm{Mg}$ and losses in $\mathrm{K}, \mathrm{Na}, \mathrm{Ca}$, and Si [27]. The XFe ratio of chlorite extends from 0.28 to 0.47 , with lower values closely corresponding to the sulphide zones and their proximal footwall halos, suggesting a strong $\mathrm{Mg}$ metasomatism during the hydrothermal emplacement of sulphides. This is similar to the Tazakourt orebody but it contrasts with the Kettara deposit where the chlorites that are associated with the mineralization are Fe-rich $(0.5<\mathrm{XFe}<0.85)$ [58]. Chlorite geothermometry suggests temperatures of 308 to $330{ }^{\circ} \mathrm{C}$ for chlorite interbedded with sulphides and chlorite from the immediately underlying footwall [27].

To conclude, Mg-chlorite characterizes the Zn-rich deposits, while Fe-rich chlorite is developed within the Kettara Cu-rich deposit and the chalcopyrite-rich vein mineralization of Hajjar. Such variations are consistent with the interpretation of McLeod and Santon [112], who have related Fe enrichment to $\mathrm{Cu}$-rich mineralization and $\mathrm{Mg}$ enrichment to $\mathrm{Zn}$-rich orebodies. The calculated temperatures are higher in the $\mathrm{Cu}$-rich orebodies than in the $\mathrm{Zn}$-rich deposits. High temperatures in Cu-rich deposits are consistent with a primary hydrothermal temperature regime [111], while low temperatures in Zn-rich orebodies can be related to seawater entrainment into the feeder zone [54]. At the regional scale, $\mathrm{Mg}$-chlorite characterizes the pervasive alteration while the Fe-rich chlorite characterizes the focused alteration within the shear zones, as exemplified by the Kettara intrusion [70].

\section{Origin and Characteristics of Hydrothermal Fluids}

\subsection{The Origin of the Fluids}

Fluid inclusion microthermometric data are presently available for the chalcopyrite-rich vein system "stockwork" of the Hajjar deposit, the Kettara Cu-deposit, and the chlorite-rich shear zones in the Kettara intrusion [17,22]. Fluid inclusions in quartz from the chalcopyrite-rich vein system that cuts across volcanic and volcaniclastic rocks in the Hajjar deposit [22] show homogenization temperatures that range from 200 to $340{ }^{\circ} \mathrm{C}$, with a mean of $280{ }^{\circ} \mathrm{C}(n=179)$. Measured salinities vary within a narrow range of 4-7 wt \% NaCl equivalent, averaging ca. $5.8 \mathrm{wt} \% \mathrm{NaCl}$ equivalent. Zouhry [22] reported that gas in these inclusions is $\mathrm{CO}_{2}$-rich and it contains $\mathrm{CH}_{4}$ and $\mathrm{N}_{2}$ with up to $7 \mathrm{~mol} \% \mathrm{CH}_{4}$.

In the Kettara deposit, the measured salinities are around $7.5 \mathrm{wt} \% \mathrm{NaCl}$ equivalent (3.4-11.6 range). The homogenization temperatures range from 174 to $376{ }^{\circ} \mathrm{C}(n=73)$. $\mathrm{CH}_{4}$ or a mixture of $\mathrm{CH}_{4}$ and $\mathrm{N}_{2}$ always dominates the volatile species of the primary fluid inclusions in the quartz that is associated with pyrrhotite [17]. Preliminary microthermometric data on Sidi M'barek $\mathrm{Cu}$-lenses indicate relatively higher salinities, which range from 8.4 to $14.5 \mathrm{wt} \% \mathrm{NaCl}$ equivalent and homogenization temperatures in the range of $170-290{ }^{\circ} \mathrm{C}$ [113].

In the quartz-chlorite veins that are associated with the shear zones cutting across the Kettara intrusion, homogenization temperatures of primary fluid inclusions range from 149 to $415^{\circ} \mathrm{C}(n=83)$. The measured salinities are higher than $23 \% \mathrm{NaCl}$ equivalent and $\mathrm{CO}_{2}$ is the dominant volatile species [17]. The abundance of $\mathrm{CH}_{4}$ and $\mathrm{N}_{2}$ in the Kettara deposit is consistent with a reduced nature of the mineralized fluids, which is likely equilibrated with the host schist. The oxidizing character 
that is outlined by the abundance of $\mathrm{CO}_{2}$ in the shear zones within the Kettara intrusion and in the Hajjar chalcopyrite-rich vein system may indicate that the fluids migrated along the zones of intense hydrothermal alteration and their reduction in situ by interaction with organic matter-rich host rocks resulted in the deposition of sulphides.

Oxygen and hydrogen isotopic compositions have been measured for the Koudiat Aicha Zn-rich deposit; the Kettara Cu-deposit; and, the shear zones in the Kettara intrusion [17,27]. Preliminary whole rock $\delta^{18} \mathrm{O}$ values of the felsic magmatic rocks range from 8.69 to $9.53 \%$ (VSMOW) and they lie within or are slightly higher than the composition of magmatic waters [114].

In Koudiat Aicha, the $\mathrm{O}$ and $\mathrm{H}$ isotopes have been measured in quartz, amphibole, muscovite, chlorite, albite, and whole rocks in metapelites, gabbros, and felsic rocks from both the footwall and the hanging wall of the deposit [27]. The $\delta^{18} \mathrm{O}$ and $\delta \mathrm{D}$ values that were calculated for hydrothermal fluids vary in a narrow range $(+6.9$ to +12.5 , and -52 to -28 , respectively) for all magmatic and metamorphic whole rocks as well as for mineral pairs. These $\delta^{18} \mathrm{O}$ and $\delta \mathrm{D}$ data indicate that magmatic and/or metamorphic waters dominate in the hydrothermal system (Figure 8). No significant isotopic variations have been observed across the footwall and hanging wall, or even between the different lithological units. The temperatures of deposition that are calculated using geothermometer pairs range from $\sim 310$ to $380{ }^{\circ} \mathrm{C}[27]$.

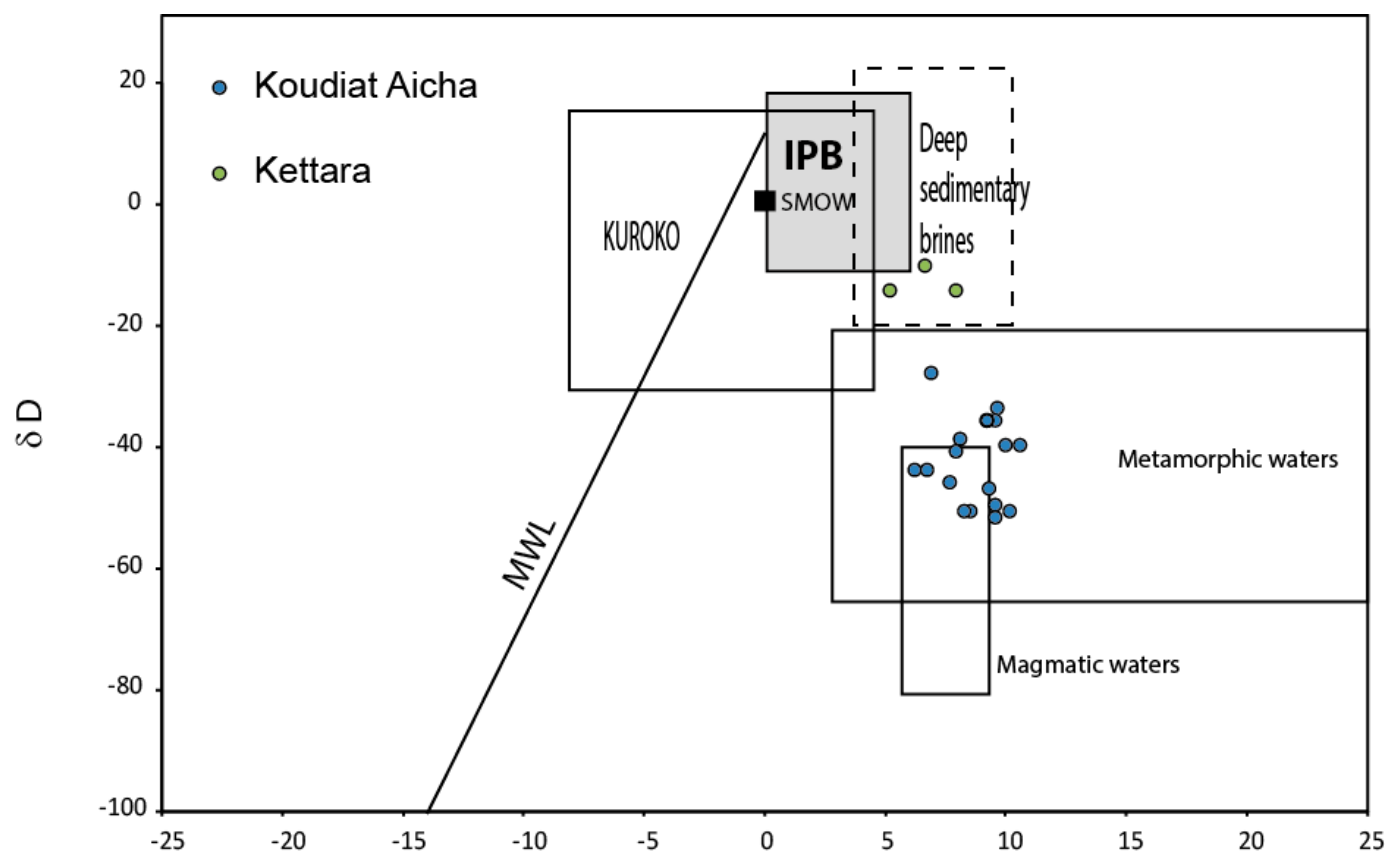

$\delta{ }^{18} \mathrm{O}$

Figure 8. $\delta \mathrm{D}$ and $\delta^{18} \mathrm{O}$ values of ore forming fluids in Koudiat Aicha and Kettara deposits as compared to those of the Iberian Pyrite Belt (IPB) (grey box) and fluids from other reservoirs. Data from [115-117].

In the Kettara deposit, the $\mathrm{O}$ and $\mathrm{H}$ isotopes have been measured in chlorite and quartz that are associated with pyrrhotite. $\delta^{18} \mathrm{O}$ values of chlorite are in the range 6.24-7.8\% (VSMOW) and $\delta \mathrm{D}$ values lie between $-52 \%$ and $-48 \%$ (VSMOW). $\delta^{18} \mathrm{O}$ and $\delta \mathrm{D}$ values of quartz are, respectively, 9.1\%0 and $-52 \%$ (VSMOW). In addition, $\delta^{18} \mathrm{O}$ values of chlorite from the shear zones in the Kettara intrusion are in the range $4.4-6.0 \%$ (VSMOW) and the $\delta \mathrm{D}$ value of chlorite is $-52 \%$ (VSMOW). The $\delta^{18} \mathrm{O}$ value of quartz from the Kettara shear zones is $9.8 \%$ (VSMOW). The oxygen isotopic composition of chlorite from the Kettara deposit is thus very similar to that of chlorite from the chlorite-rich shear zones, indicating that alteration in the deposit and the intrusion could be related to the same hydrothermal activity. Similarly, the $\delta^{18} \mathrm{O}$ isotopic compositions of quartz from the Kettara deposit 
and from quartz-chlorite veins that are associated with the shear zones within the intrusion are very similar, indicating that the formation of both the mineralized and unmineralized veins could be related to the same fluids.

The calculated oxygen isotopic composition of the hydrothermal fluid in the Kettara intrusion and the nearby ore deposit lie between 6.0\% and 7.2\% (VSMOW). These values are inconclusive and they could either correspond to magmatic, metamorphic, or basinal fluids [118]. For hydrogen, the $\delta \mathrm{D}$ values of the fluid are calculated to be between $-15 \%$ and $-10 \%$ (VSMOW), which are too high for magmatic fluids and more clearly point to basinal fluids (Figure 8 ). Overall, $\delta^{18} \mathrm{O}$ and $\delta \mathrm{D}$ data indicate that magmatic, metamorphic, and basinal waters were involved in the hydrothermal fluids in both Kettara and Koudiat Aicha deposits, as well as in the shear zones in the Kettara intrusion. This contrasts with VMS deposits, such as the IPB and the Kuroko deposits (Figure 8), where the circulating fluids essentially consisted in basinal waters or modified seawater.

A comparison of the oxygen isotope geochemistry with $\mathrm{Sr}$ isotopes provides additional constraints on the origin of fluids. The Sr isotopic signatures of the fluids in the Kettara intrusion at the time of the hydrothermal activity (330 Ma) share comparable Sr isotopic ratios (0.7120-0.7135) to the host schists and the coeval microgranites, leading Essaifi et al. [70] to consider that the alteration in Kettara was due to the circulation of metamorphic fluids sensu lato, i.e. dewatering metamorphic fluids, magmatic-derived fluids, or surface-derived fluids, including formation waters, which were equilibrated with host lithologies.

\subsection{The Origin of the Reduced Sulfur}

Sulphur isotopes are available for a number of deposits. In the Koudiat Aicha deposit, the $\delta^{34} \mathrm{~S}_{\mathrm{CDT}}$ values vary from $-11.6 \%$ to $-5.9 \%$, with an average of $-8.8 \%$ [26]. In the Kettara deposit, the $\delta^{34} S$ values of massive pyrrhotite vary from $-2.2 \%$ to $-0.5 \%$, with an average value of $-0.1 \%$ [119]. For the Hajjar deposit, $\delta^{34} \mathrm{~S}$ values are between -1 and $5 \%$, with a mean value at $1.5 \%$ [110,120]. In the Draa Sfar deposit, the $\delta^{34} \mathrm{~S}$ values of pyrrhotite from both the $\mathrm{Zn}$-rich and the $\mathrm{Cu}$-rich lenses are similar and they vary in a narrow range, from $-7.4 \%$ to $-6.4 \%$ (Table 2 ). $\delta^{34} S$ values of remobilized chalcopyrite replacing pyrrhotite in the $\mathrm{Cu}$-rich lenses range from $-6.1 \%$ to $-5.2 \%$, which are close to those of pyrrhotite. In contrast, pyrite crystals replacing pyrrhotite have $\delta^{34} S$ values of $-2.5 \%$ to $-0.8 \%$, which are the heaviest $\delta^{34} S$ values that were recorded in the Draa Sfar district. In addition, Ben Aissi (2008) [77] reported $\delta^{34} S$ values that were between $-6 \%$ and $-3 \%$ for the Tazakourt Zn-rich orebody. We conclude that the $\delta^{34} S$ values of Draa Sfar vary from -7.4 to $-3.0 \%$, with an average value at $-5.2 \%$ in the earliest mineralizing fluid, which led to the formation of the pyrrhotite-rich sulphide paragenesis, and from $-2.5 \%$ to $-0.8 \%$, with an average value at $-1.7 \%$ in the late mineralizing fluid, which led to the formation of pyrite-rich sulphide assemblage.

Table 2. Sulphur $\left(\delta^{34} \mathrm{~S} \%\right.$ ) isotope data of pyrrhotite, pyrite and chalcopyrite of the Sidi $\mathrm{M}^{\prime}$ Barek deposit.

\begin{tabular}{ccccc}
\hline Deposit & Lens Type & Sample No & Sample Type & $\boldsymbol{\delta}^{\mathbf{3 4}} \mathbf{S} \% 0$ \\
\hline Draa Sfar North & Cu-rich lens & 3-DS194(i) & Pyrrhotite & -6.4 \\
Draa Sfar North & Cu-rich lens & 3-DS194(ii) & Pyrrhotite & -6.7 \\
Draa Sfar North & Cu-rich lens & 3-DS194(iii) & Pyrrhotite & -7.4 \\
Draa Sfar North & Cu-rich lens & 2-DS194(i) & Pyrite vein & -0.8 \\
Draa Sfar North & Cu-rich lens & 2-DS194(ii) & Pyrite vein & -2.5 \\
Draa Sfar North & Cu-rich lens & 4-DS153(i) & Late Chalcopyrite & -6.1 \\
Draa Sfar North & Cu-rich lens & 4-DS153(i) & Late Chalcopyrite & -5.2 \\
Draa Sfar North & Zn-rich lens & DF $^{*}$ & Pyrrhotite & -7.2
\end{tabular}

* Sample collected from an underground exploitation level while the other samples are from the drill cores 153 and 194.

In the Figure $9, \delta^{34} \mathrm{~S}$ values of the MMSD are shown together with those of the IPB and other volcanic-hosted and sediment hosted massive sulphide deposits. The $\delta^{34} S$ values of the MMSD 
vary from $-11.6 \%$ to $5 \%$. Such a range is relatively narrow when compared to the IPB (-42\%0 to + 10\%) [121-124]. The lowest values in the MMSD (down to -11.6\%) come from the Koudiat Aicha deposit. According to Lotfi et al. [26], such isotopic signatures argue against a magmatic origin and suggest the derivation of sulfur from host rocks and/or seawater. This is not the case in the Kettara deposit, where the $\delta^{34} S$ values show a remarkably narrow range of $\delta^{34} S$ values around $0 \%$, indicating that the mineralizing fluid did not incorporate large quantities of $S$ from the country rocks. Such values, which range from $-2.2 \%$ to $-0.5 \%$, are consistent with magmatic derivation, either via exsolution of magmatic fluids or leaching of igneous rocks $[125,126]$. More importantly, Figure 9 shows that each deposit has a distinctive sulfur isotopic signature, with Koudiat Aicha, and Hajjar deposits showing, respectively, the lowest and the highest signatures, while the Draa Sfar, and Kettara deposits show intermediate ones. This contrasts with the IPB, where there is a difference between the shale hosted and the volcanic hosted sulphide deposits [10].

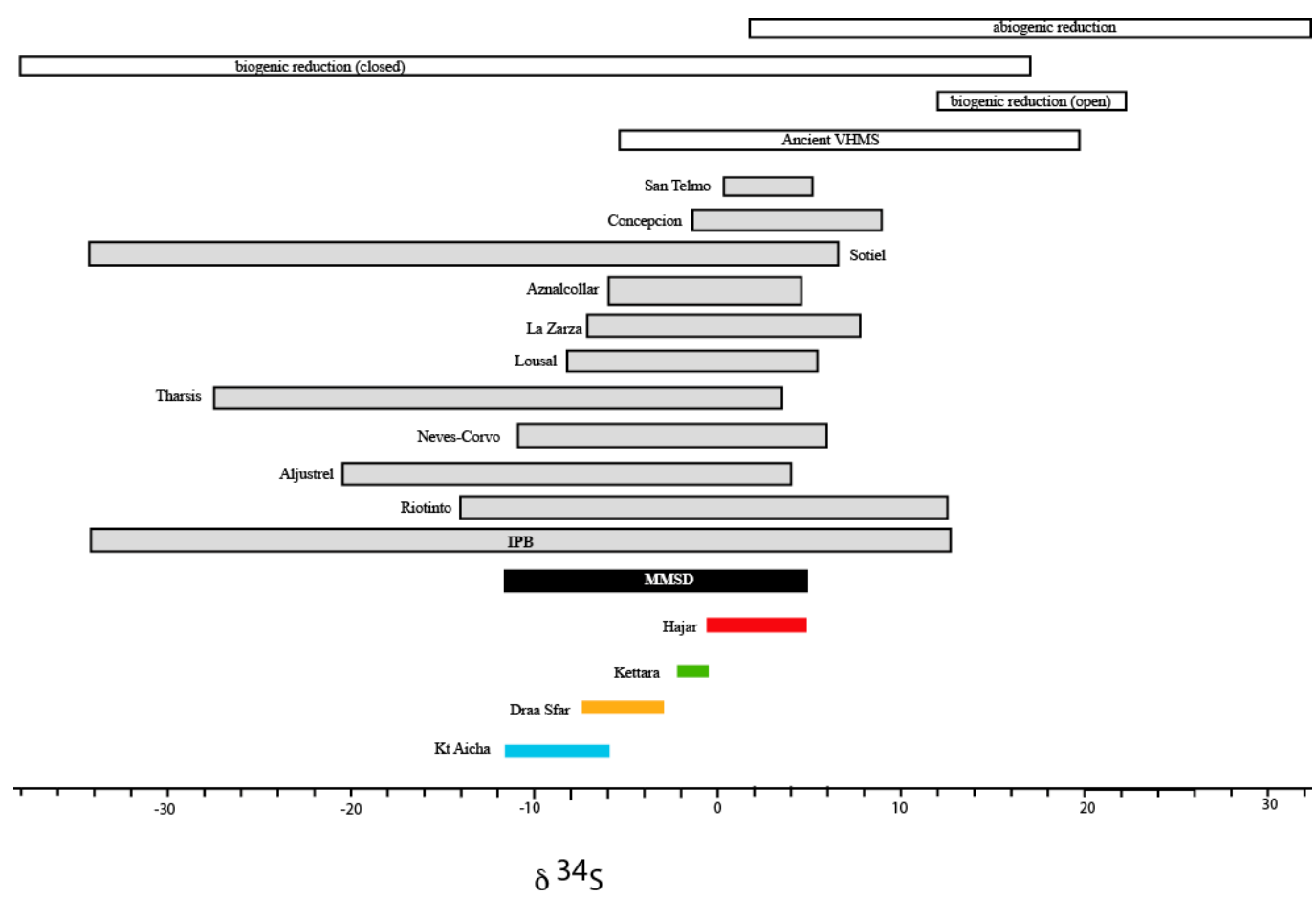

Figure 9. Sulphur isotopes of the main MMSD compared to those of the IPB [121] and the other ancient volcanic-hosted massive sulphides [125-131]. The field of reduced sulphur inherited from the abiogenic reduction of seawater is estimated from [132] and the interval for biogenic reduction sulphate is from [116].

The narrow range of the sulphur isotopic signatures within each deposit contrasts with the large spread of the isotopic signatures at the district scale. This large spread may reflect the different contributions of abiogenic and biogenically reduced sulphur [129]. The marked sulphur isotopic signature variation between the deposits belonging to the same district indicates different metallogenic environments and different chemical conditions in ore solutions. Such differences exist, even between the Zn-rich deposits of Hajjar, Draa Sfar, and Koudiat Aicha, and they may be related to the occurrence of the deposits in small-scale, relatively closed anoxic sedimentary sub-basins. The sulfur isotopic ratios of pyrite, representing the late stage mineralization, show almost the same values in the Jebilet and Guemassa deposits [76] and overlap those in the Sidi M'barek deposit. These similar signatures indicate that the differences in the sources of sulphur that prevailed during the earliest mineralizing stage have disappeared. The syntectonic to late tectonic growth of pyrite indicates that such "homogenization" is likely due to a shift from local sedimentary environments to a more uniform metamorphic one. 


\subsection{The origin of Metals}

Lead isotopes are available for some deposits $[18,22,133,134]$ (Figure 10). For the Hajjar deposit, the ${ }^{206} \mathrm{~Pb} /{ }^{204} \mathrm{~Pb}$ ratios of six-galena samples range between 18.165 and 18.205 [22]. For the Koudiat Aicha deposit, the ${ }^{206} \mathrm{~Pb} /{ }^{204} \mathrm{~Pb}$ ratios are similar at $\sim 18.28$ for two sulphide samples, while two gossan samples are slightly more radiogenic, with ${ }^{206} \mathrm{~Pb} /{ }^{204} \mathrm{~Pb}$ ratios at 18.33 and 18.37 [27]. For the Kettara deposit, lead isotopic values [134] indicate ${ }^{206} \mathrm{~Pb} /{ }^{204} \mathrm{~Pb}$ ratios between 18.28 and 18.43 for massive pyrrhotite and gossan samples.

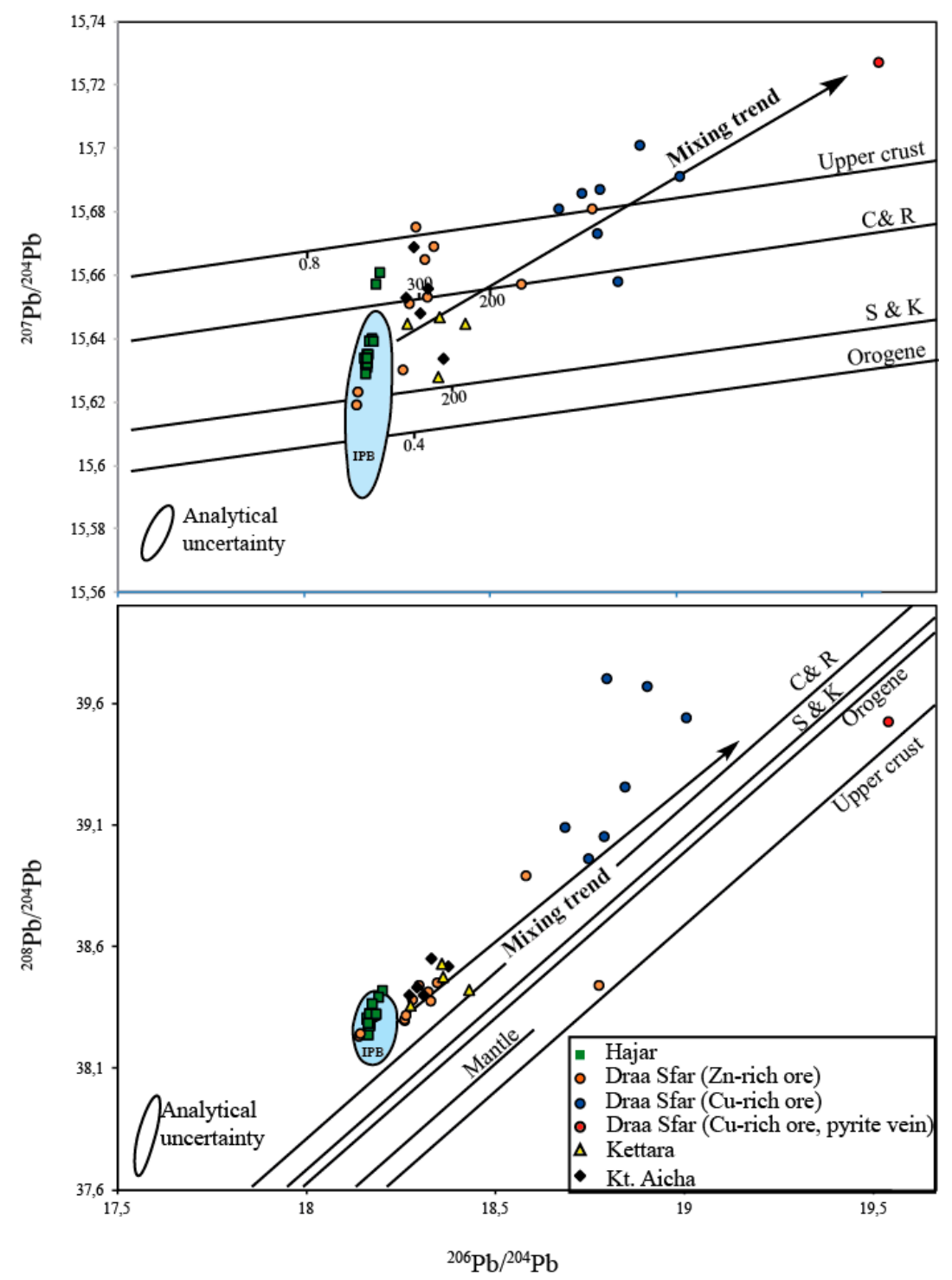

Figure 10. Lead isotopic compositions of the MMSD as compared to the lead isotopic compositions of the IPB VMS deposits (Blue field; [135]). Data from [18,22,133,134]; S and K: average growth curve of Stacey and Kramers [136], C and R: upper crust growth curve of Cumming and Richards [137]. Evolution curves for Upper Crust and Orogene [138] are shown for reference.

For the Draa Sfar deposit, samples of a mixture of sulphides from Sidi M'Barek yielded ${ }^{206} \mathrm{~Pb} /{ }^{204} \mathrm{~Pb}$ ratios that were between 18.143 and 18.776 in the $\mathrm{Zn}$-rich lens and between 18.687 and 19.01 in the $\mathrm{Cu}$-rich lens, while a quartz-pyrite vein yielded ${ }^{206} \mathrm{~Pb} /{ }^{204} \mathrm{~Pb}$ ratio of 19.543 [134]. Marcoux et al. [18] noted that the lead isotopic signatures track in Draa Sfar the existence of lead from 
two sources, a low radiogenic one (with ${ }^{206} \mathrm{~Pb} /{ }^{204} \mathrm{~Pb}$ close to 18.28 ) that dominated in the $\mathrm{Zn}$-rich lens and a more radiogenic source $\left({ }^{206} \mathrm{~Pb} /{ }^{204} \mathrm{~Pb} \sim 19.01\right)$ that was predominant in the Cu-rich lenses.

The striking feature of the $\mathrm{Pb}$ isotopic signatures of the MMSD is their heterogeneity as compared to those of the IPB (see [135]; Figure 10). The magnitude of this heterogeneity is even larger than that of the Miocene Kuroko VMS deposits $[139,140]$. The less radiogenic $\mathrm{Pb}$ isotopic values are represented by the samples from the Hajjar and Draa Sfar deposits, which are similar to those of the IPB. The more radiogenic $\mathrm{Pb}$ is represented by a sample of pyrite from the late syn-tectonic vein. The other data points form broad linear arrays, suggesting the mixing of $\mathrm{Pb}$ between these two contrasting end-members. However, the source of lead cannot be identified with certainty, because lead isotopic signatures of the host rocks are not available. Nevertheless, Marcoux et al. [18] and Bouabdellah et al. [64] consider that the least radiogenic signatures are similar to those of the Visean igneous rocks of the Iberian Pyrite Belt and the eastern Meseta, and they suggest a major contribution of volcanic rocks as a source of metals. The lead isotope signature of the Cu-rich lens at Draa Sfar plots close to the Zartman and Doe [138] upper crust evolutionary curve, and it suggests that most of the lead is inherited from the hosting Sarhlef Schists $[18,64]$. A magmatic source of metals is strengthened by the fact that the less radiogenic signatures are recorded in Draa Sfar South and Hajjar deposits, which are associated with volcanic rocks. In contrast, the most radiogenic signatures that are recorded in the pyrite veins crosscutting pyrrhotite at Sidi M'Barek probably mark a late contribution of even more radiogenic lead during the syn-metamorphic mineralization, coeval with low-grade metamorphism, and emplacement of mafic-dominated intrusive rocks.

\section{Discussion-Genetic Model}

The study of the main massive sulphide deposits in the Jebilet-Guemassa area records the existence of an early mineralizing stage that is dominated by pyrrhotite and a late stage dominated by pyrite. The early stage is represented by the precipitation of pyrrhotite \pm chalcopyrite, sphalerite, and galena, forming massive or banded ores. They are accompanied by variable amounts of quartz, chlorite, and sericite. These ore bodies show evidence of widespread deformation and shearing, and they are clearly pre- to syn-tectonic, as indicated by the development of pressure fringes around sphalerite and arsenopyrite grains and by the presence pyrite infilling veins cross-cutting pyrrhotite (Figure 4f,h). The late mineralizing event is represented by the growth of pyrite replacing earlier pyrrhotite and the precipitation of carbonates. Textural evidence indicates that pyrite is syn- to late-tectonic (Figure $4 \mathrm{~g}, \mathrm{~h}$ ). Local remobilization of chalcopyrite along later fractures postdates the pyritic stage.

VMS deposits most commonly occur in the second or third order basins that formed in an extensional basin during the stage of intense rifting and subsidence [141]. Although the sulfur isotopic signature of the earliest mineralizing fluid is consistent with the VMS model, each studied deposit has a distinctive signature, suggesting that local setting/depositional environments prevailed in each deposit. As the MMSD are located within structural lineaments that are parallel to linear arrays of magmatic bodies, we propose that the distinctive sulphur isotopic signatures indicate a subdivision of the Central Jebilet sedimentary basin into individual sub-basins where the Upper Visean black shales were deposited and magmatic rocks were emplaced along N-S to NE-SW synsedimentary fractures. This paleogeography is further indicated by the general absence of lateral correlations between the local stratigraphic successions of the ore deposits, which reflect very sharp facies variations. The formation of these sub-basins was favored by translithospheric transtension at the intersection between the NNE-trending WMSZ and the WNW-trending MSZ. In accordance with the transtensional systems in which boundary walls are non-parallel [142], the N-S to NNE-SSW shear zones that characterize the Central Jebilet area were originally extensional synsedimentary faults that trend at a low angle to the MSZ and WMSZ that bound the Central Jebilet triangular block.

At depth, asthenospheric upwelling, partial melting of crustal rocks, and magma ascent to high crustal levels promoted a high heat flow along this structural corridor. The emplacement of felsic-dominated domes along the synsedimentary faults allowed for the formation of ridges that 
isolate these sub-basins. Hydrothermal activity that is associated with magma emplacement and seismic pumping resulted in the formation of pyrrhotite-rich VMS bodies that are concentrated along the synsedimentary faults. The high sedimentation rates of the black shales (e.g., 19-27 cm/ ka for Draa Sfar) [75] favored the accumulation of organic material and the isolation of the massive sulphides from the ambient seawater. The lead isotopic signature of this event points to a magmatic origin. However, a specific depositional environment characterized each sub-basin. Several studies have demonstrated a close spatial and temporal relationship between VMS mineralization and the formation of small-scale, second, or third-order basins, e.g., [143-145]. Especially, oblique deformation with the formation of pull-apart sub-basins along strike-slip faults is particularly important, because these structures localize magmatism and focus fluid flow [5,142,146,147].

Rapidly, after the deposition of the Sarhlef Schists, rotation of the stress axes induced an evolution from transtension to transpression. This evolution took place while magma production was still active and syntectonic intrusions were emplaced at ca. $330 \mathrm{Ma}$ into slightly older upper Visean (350-333 Ma) marine metasediments $[20,39,55,57]$. Synchronously, the extensional synsedimentary faults evolved to ductile shear zones and the basins were closed. This basin inversion and compression resulted in the deformation of the previously formed pyrrhotite-rich deposits. The original features of the pyrrhotite-rich deposits were almost completely obliterated by remobilization and deformation, and the orebodies were rearranged to steeply dipping ore lenses. The combined effects of deformation and hydrothermal alteration resulted in the leaching of base metals from the felsic intrusions [25] and the formation of chlorite-rich shear zones in the mafic intrusions [17,70], which is consistent with the recorded $\mathrm{O} / \mathrm{H}$ isotopic values. More importantly, basin inversion and compression homogenized the hydrothermal systems and a later, syn-tectonic one, which is dominated by pyrite with homogeneous sulphur isotope values, superimposed the primary mineralization. The lead isotopic signature of this late event is significantly more radiogenic than that of the early mineralization and it points out to the metals being inherited from the hosting black shales [18].

The replacement of pyrrhotite by pyrite can occur either by sulfidation reaction or Fe-loss from pyrrhotite, i.e. without need of an external source of sulphur, or by the addition of an external oxidant [148]. Fe-loss from pyrrhotite can be ruled out, because the $\delta^{34} S$ of pyrite is different from that of pyrrhotite, which indicates that there was the addition of external sulphur [149].

The host sequence of the MMSD, dominated by siliciclastic rocks that are deposited in a continental margin basin, is consistent with the 'siliciclastic' class of VMS deposits that is defined by Franklin et al. [3], which includes the Bathurst Mining Camp and the IPB. In the Moroccan Meseta, a rapid evolution from transtension to transpression occurred while magma production was still active, and it makes the MMSD peculiar in the 'siliciclastic' class of VMS deposits. In contrast to the Iberian deposits, the MMSD consist of pyrrhotite rather than pyrite, and they are hosted by middle to upper Visean metasediments, while Late Devonian to Early Tournaisian rocks host those of the Iberian Pyrite Belt [150]. Moreover, the $\mathrm{O} / \mathrm{H}$ and $\mathrm{Pb}$ isotopic signatures of the MMSD are significantly different from those of the Iberian Pyrite Belt.

\section{Conclusions}

The massive sulphide deposits of the Moroccan Meseta occur in a crustal block that is characterized by the presence of high-temperature (i.e., $>900{ }^{\circ} \mathrm{C}$ ) bimodal magmatism and bounded by two major fractures. Magmatism was long lived and it evolved from felsic volcanic rocks that were emplaced during Visean transtension and coeval with siliciclastic sedimentation, to syn-tectonic bimodal intrusive rocks emplaced during Late-Visean-Namurian transpression and metamorphism. This multi-phase and long-lived subvolcanic magmatic activity reflects a sustained thermally anomalous geodynamic environment, in which a significant hydrothermal circulation occurred. The hydrothermal activity was initiated during transtension and emplacement of the earliest magmatic rocks, and it was accompanied by the formation of shale-hosted volcanic massive sulphide (VMS) deposits controlled by synsedimentary faults. The hydrothermal activity was 
maintained during the evolution from transtension to transpression and the emplacement of shallow level syntectonic intrusions. Synchronously, the synsedimentary faults evolved to ductile shear zones, which resulted in the deformation and remobilization of the VMS deposits and the circulation of metamorphic fluids along major structures. During this evolution, the mineralization evolved from pyrrhotite-dominated to pyrite-dominated. The involved fluids also changed from basinal fluids to metamorphic-dominated fluids, while the contribution of metals was shifted from a magmatic-dominated to black shale-dominated source. Late remobilization of copper along ductile-brittle fractures resulted in chalcopyrite-rich mineralization.

Author Contributions: Investigation, A.E., K.G. and A.O. (Abdelhak Outigua); Validation, A.O. (Abdelmalek Ouadjou) and L.M.; Writing - original draft, A.E.; Writing-review \& editing, A.E., K.G. and F.T.

Funding: This work received a financial support from the project URAC 43. The collaboration of F. Tornos is a contribution to the Spanish SEIDI CGL-2011-23207 project.

Acknowledgments: We wish to thank A. Boyce from the SUERC for providing the sulphur isotope data used in this study. Discussions with P. Lusty and A.M. Lacinska from the BGS, M. Zouhair, M. Outhounjite and A. Khalifa from Managem, were greatly appreciated.

Conflicts of Interest: The authors declare there are no known conflict of interest.

\section{References}

1. Shanks, W.C.; Thurston, R. Volcanogenic Massive Sulphide Occurrence Model; USGS Scientific Investigations Report 2010-5070-C; USGS: Reston, VA, USA, 2012.

2. Lydon, J.W. Ore deposit models \#14, volcanogenic massive sulphide deposits Part 2: Genetic models. Geosci. Can. 1988, 15, 43-65.

3. Franklin, J.M.; Gibson, H.L.; Jonasson, I.R.; Galley, A.G. Volcanogenic Massive Sulphide Deposits. Econ. Geol. 2005, 100, 523-560.

4. Galley, A.G.; Hannington, M.; Jonasson, I. Volcanogenic massive sulphide deposits. In Mineral Deposits of Canada: A Synthesis of Major Deposit-Types, District Metallogeny, the Evolution of Geological Provinces, and Exploration Methods; Goodfellow, W.D., Ed.; Mineral Deposits Division, Geological Association of Canada: St. John's, NL, Canada, 2007; Special Publication 5; pp. 141-161.

5. Huston, D.L.; Pehrsson, S.; Eglington, B.M.; Zaw, K. The Geology and Metallogeny of Volcanic-Hosted Massive Sulphide Deposits: Variations through Geologic Time and with Tectonic Setting. Econ. Geol. 2010, 105, 571-591. [CrossRef]

6. Tornos, F.; Peter, J.M.; Allen, R.; Conde, C. Controls on the siting and style of volcanogenic massive sulphide deposits. Ore Geol. Rev. 2015, 68, 142-163. [CrossRef]

7. Hannington, M.D.; De Ronde, C.E.J.; Petersen, S. Sea-floor Tectonics and Submarine Hydrothermal Systems. Econ. Geol. 2005, 100, 111-141.

8. Barrie, C.; Hannington, M. Classification of volcanic-associated massive sulphide deposits based on host-rock composition. Rev. Econ. Geol. 1999, 8, 1-11.

9. Goodfellow, W.D.; McCutcheon, S.R.; Peter, J. Massive sulphide deposits of the Bathurst Mining Camp, New Brunswick and Northern Maine: Introduction and summary of findings. Econ. Geol. Monogr. 2003, 11, 1-16.

10. Tornos, F. Environment of formation and styles of volcanogenic massive sulphides: The Iberian Pyrite Belt. Ore Geol. Rev. 2006, 28, 259-307. [CrossRef]

11. Marshall, B.; Gilligan, L.B. Structural setting and controls on mineral deposits remobilization, syn-tectonic processes and massive sulphide deposits. Ore Geol. Rev. 1993, 8, 39-64. [CrossRef]

12. Marshall, B.; Spry, P. Discriminating between regional metamorphic remobilization and syntectonic emplacement in the genesis of massive sulphide ores. Rev. Econ. Geol. 2000, 11, 39-80.

13. Castroviejo, R.; Quesada, C.; Soler, M. Post-depositional tectonic modification of VMS deposits in Iberia and its economic significance. Mineral. Depos. 2011, 46, 615-637. [CrossRef]

14. Leistel, M.J.; Marcoux, E.; Thiéblemont, D.; Quesada, C.; Sánchez, A.; Almodóvar, R.G.; Pascual, E.; Sáez, R. The volcanic-hosted massive sulphide deposits of the Iberian Pyrite Belt. Mineral. Depos. 1997, 33, 2-30. [CrossRef] 
15. Saez, R.; Pascual, E.; Toscano, M.; Almodóvar, G.R. The Iberian type of volcano-sedimentary massive sulphide deposits. Mineral. Depos. 1999, 34, 549-570. [CrossRef]

16. Huvelin, P. Etude géologique et gîtologique du massif hercynien des Jebilet (Maroc occidental). Notes Mém. Serv. Géol. Maroc 1977, 232, 307.

17. N’Diaye, I.; Essaifi, A.; Dubois, M.; Lacroix, B.; Goodenough, K.M.; Maacha, L. Fluid flow and polymetallic sulphide mineralization in the Kettara shear zone (Jebilet Massif, Variscan Belt, Morocco). J. Afr. Earth Sci. 2016, 119, 17-37. [CrossRef]

18. Marcoux, E.; Belkabir, A.; Gibson, H.L.; Lentz, D.; Ruffet, G. Draa Sfar, Morocco: A Visean (331 Ma) pyrrhotite-rich, polymetallic volcanogenic massive sulphide deposit in a Hercynian sediment-dominant terrane. Ore Geol. Rev. 2008, 33, 307-328. [CrossRef]

19. Belkabir, A.; Gibson, H.L.; Marcoux, E.; Lentz, D.; Rziki, S. Geology and wall rock alteration at the Hercynian Draa Sfar Zn-Pb-Cu massive sulphide deposit, Morocco. Ore Geol. Rev. 2008, 33, 280-306. [CrossRef]

20. Moreno, C.; Sáez, R.; González, F.; Almodóvar, G.; Toscano, M.; Playford, G.; Alansari, A.; Rziki, S.; Bajddi, A. Age and depositional environment of the Draa Sfar massive sulphide deposit, Morocco. Mineral. Depos. 2008, 43, 891-911. [CrossRef]

21. Bernard, A.J.; Maier, O.W.; Mellal, A. Aperçu sur les amas sulfurés massifs des hercynides Marocaines. Mineral. Depos. 1988, 23, 104-114. [CrossRef]

22. Zouhry, S. Etude métallogénique d'un amas sulfuré viséen à Zn-Pb-Cu: Cas de Hajjar, Guemassa, Maroc. Ph.D. Thesis, École Polytechnique de Montréal, Montreal, QC, Canada, 1999.

23. Hibti, M.; Marignac, C. The Hajjar deposit of Guemassa (SW Meseta, Morocco): A metamorphosed syn-sedimentary massive sulphide ore body of the Iberian type of volcano-sedimentary massive sulphide deposits. In Mineral Deposits at the Beginning of the 21st Century, Proceedings of the Joint Sixth Biennial SGA-SEG Meeting, Krakow, Poland, 26-29 August 2001; A.A. Balkema: Lisse, The Netherlands, 2001; pp. 281-284.

24. Admou, S.; Branquet, Y.; Badra, L.; Barbanson, L.; Outhounjite, M.; Khalifa, A.; Zouhair, M.; Maacha, L. The Hajjar Regional Transpressive Shear Zone (Guemassa Massif, Morocco): Consequences on the Deformation of the Base-Metal Massive Sulphide Ore. Minerals 2018, 8, 435. [CrossRef]

25. Essaifi, A.; Hibti, M. The hydrothermal system of Central Jebilet (Variscan Belt, Morocco): A genetic association between bimodal plutonism and massive sulphide deposits? J. Afr. Earth Sci. 2008, 50, 188-203. [CrossRef]

26. Lotfi, F.; Belkabir, A.; Brown, A.C.; Marcoux, E.; Brunet, S.; Maacha, L. Geology and Mineralogy of the Hercynian Koudiat Aïcha Polymetallic ( $\mathrm{Zn}-\mathrm{Pb}-\mathrm{Cu}$ ) Massive Sulphide Deposit, Central Jebilet, Morocco. Explor. Min. Geol. 2008, 17, 145-162. [CrossRef]

27. Lotfi, F.; Belkabir, A.; Brunet, S.; Brown, A.C.; Marcoux, E. Lithogeochemical, mineralogical analyses and oxygen-hydrogen isotopes of the Hercynian Koudiat Aïcha massive sulphide deposit, Morocco. J. Afr. Earth Sci. 2010, 56, 150-166. [CrossRef]

28. Michard, A.; Soulaimani, A.; Hoepffner, C.; Ouanaimi, H.; Baidder, L.; Rjimati, E.C.; Saddiqi, O. The South-Western Branch of the Variscan Belt: Evidence from Morocco. Tectonophysics 2010, 492, 1-24. [CrossRef]

29. Baudin, T.; Chèvremont, P.; Razin, P.; Youbi, N.; Andries, D.; Hoepffner, C.; Tegyey, M. Carte géologique du Maroc au 1/50 000, feuille de Skhour des Rehamna, Mémoire explicatif. Notes Mém. Serv.Géol. Maroc 2003, 435,114 .

30. Lagarde, J.L.; Ait Omar, S.; Roddaz, B. Structural characteristics of granitic plutons emplaced during weak regional deformation: Examples from late Carboniferous plutons, Morocco. J. Struct. Geol. 1990, 12, 805-821. [CrossRef]

31. Michard, A.; Hoepffner, C.; Soulaimani, A.; Baidder, L. The Variscan Belt. In Continental Evolution: The Geology of Morocco; Michard, A., Saddiqi, O., Chalouan, A., Frizon de Lamotte, D., Eds.; Lecture Notes in Earth Sciences; Springer: Berlin/Heidelberg, Germany, 2008; Volume 116, pp. 65-131.

32. Clauer, N.; Jeannette, D.; Tisserant, D. Datation isotopique des cristallisations successives d'un socle cristallin et cristallophyllien, Haute Moulouya, Moyen Atlas. Geol. Rundsch. 1980, 69, 63-83. [CrossRef]

33. Huon, S.; Piqué, A.; Clauer, N. Etude de l'orogenèse hercynienne au Maroc par la datation K/Ar de l'évolution métamorphique de schistes ardoisiers. Sci. Géol. Bull. Strasbourg 1987, 40, 273-284.

34. Piqué, A.; Jeannette, D.; Michard, A. The Western Meseta Shear Zone, a major and permanent feature of the Hercynian belt in Morocco. J. Struct. Geol. 1980, 2, 55-61. [CrossRef]

35. Essaifi, A.; Lagarde, J.L.; Capdevila, R. Deformation and displacement from shear zone patterns in the Variscan upper crust, Jebilet, Morocco. J. Afr. Earth Sci. 2001, 32, 335-350. [CrossRef] 
36. Piqué, A.; Michard, A. Moroccan Hercynides; a synopsis; the Paleozoic sedimentary and tectonic evolution at the northern margin of West Africa. Am. J. Sci. 1989, 289, 286-330. [CrossRef]

37. Mayol, S.; Muller, J. Mise en évidence d'une unité allochtone hercynienne précoce (antéschisteuse) dans les Jebilet occidentales (Maroc). Etude de structuration de la zone de contact. C. R. Acad. Sci. Paris 1985, 300, 369-372.

38. Le Corre, C.; Bouloton, J. Un modèle de 'structure en fleur' associant décrochement et convergence: Les Jebilet centro-occidentales (Maroc hercynien). C. R. Acad. Sci. Paris 1987, 13, 751-755.

39. Playford, G.; González, F.; Moreno, C.; Al Ansari, A. Palynostratigraphy of the Sarhlef Series (Mississippian), Jebilet Massif, Morocco. Micropaleont 2008, 54, 89-124.

40. Delchini, S.; Lahfid, A.; Plunder, A.; Michard, A. Applicability of the RSCM geothermometry approach in a complex tectono-metamorphic context: The Jebilet massif case study (Variscan Belt, Morocco). Lithos 2016, 256-257, 1-12. [CrossRef]

41. Graham, J.R. Transition from basin-plain to shelf deposits in the Carboniferous flysch of Southern Morocco. Sediment. Geol. 1982, 33, 173-193. [CrossRef]

42. Graham, J.R. Wave-Dominated Shallow-Marine Sediments in the Lower Carboniferous of Morocco. J. Sediment. Petrol. 1982, 52, 1271-1276.

43. Beauchamp, J. Le Carbonifere inferieur des Jebilet et de l'Atlas de Marrakech (Maroc); Migration et comblement d'un bassin marin. Bull. Soc. Geol. Fr. 1984, 7, 1025-1032. [CrossRef]

44. Beauchamp, J.; Izart, A. Early Carboniferous basins of the Atlas-Meseta domain (Morocco): Sedimentary model and geodynamic evolution. Geology 1987, 15, 797-800. [CrossRef]

45. Izart, A.; Beauchamp, J.; Vachard, D.; Tourani, A.-I.; Essamani, M. Stratigraphie séquentielle du Carbonifère inférieur du Haut Atlas central et des Jebilet (Maroc): Un exemple de bassins à turbidites contrôlées par la tectonique. J. Afr. Earth Sci. 1997, 24, 445-454. [CrossRef]

46. Lagarde, J.L. Granites Tardi-Carbonifères et Déformation Crustale: L'exemple de la Meseta Marocaine; Mémoires et Documents du CAESS, n²6; Rennes I University: Rennes, France, 1989; pp. 1-342.

47. Hoepffner, C.; Soulaimani, A.; Piqué, A. The Moroccan Hercynides. J. Afr. Earth Sci. 2005, 43, 144-165. [CrossRef]

48. Lagarde, J.L.; Choukroune, P. Cisaillement ductile et granitoides syntectoniques; l'exemple du Massif Hercynien des Jebilet (Maroc). Bull. Soc. Géol. Fr. 1982, 7, 299-307. [CrossRef]

49. Beauchamp, J.; Izart, A.; Piqué, A. Les bassins d'avant-pays de la chaîne hercynienne au Carbonifère inférieur. Can. J. Earth Sci. 1991, 28, 2024-2041. [CrossRef]

50. Bordonaro, M.; Gaillet, J.L.; Michard, A. Le géosynclinal carbonifère sud-mésetien dans les Jebilet (Maroc): Une corrélation avec la province pyriteuse du Sud de l’Espagne. C. R. Acad. Sci. Paris 1979, 288, 1371-1374.

51. Bordonaro, M. Tectonique et Petrographique du District à Pyrrhotine de Kettara (Paleozoique des Jebilet, Maroc). Ph.D. Thesis, Louis Pasteur University, Strasbourg, France, 1983.

52. Aarab, E.; Beauchamp, J. Le magmatisme carbonifère pré-orogénique des Jebilet centrales (Maroc). Précisions pétrographiques et sédimentaires. Implications géodynamiques. C. R. Acad. Sci. Paris 1987, 304, 169-174.

53. Essaifi, A.; Samson, S.; Goodenough, K. Geochemical and Sr-Nd isotopic constraints on the petrogenesis and geodynamic significance of the Jebilet magmatism (Variscan Belt, Morocco). Geol. Mag. 2014, 151, 666-691. [CrossRef]

54. Large, R.R. Australian volcanic-hosted massive sulphide deposits: Features, styles, and genetic models. Econ. Geol. 1992, 87, 471-510. [CrossRef]

55. Essaifi, A.; Potrel, A.; Capdevila, R.; Lagarde, J.L. Datation U/Pb: Âge de mise en place du magmatisme bimodal des Jebilet centrales (chaîne Varisque, Maroc). Implications géodynamiques. C. R. Geosci. 2003, 335, 193-203. [CrossRef]

56. Delchini, S.; Lahfid, A.; Lacroix, B.; Baudin, T.; Hoepffner, C.; Guerrot, C.; Lach, P.; Saddiqi, O.; Ramboz, C. The Geological Evolution of the Variscan Jebilet Massif, Morocco, inferred from new Structural and Geochronological Analyses. Tectonics 2018, 37, 4470-4493. [CrossRef]

57. Mrini, Z.; Rafi, A.; Duthou, J.L.; Vidal, P. Chronologie Rb-Sr des granitoïdes hercyniens du Maroc: Conséquences. Bull. Soc. Geol. Fr. 1992, 163, 281-291.

58. Souaré, A.T. Contribution à l'étude des amas sulphurés du district des Jebilet centrales et de leurs altérations supergènes (chapeau de fer). Comparaison avec les minéralisations sulphurées d'Agouim (Haut Atlas, Maroc). Ph.D. Thesis, Cadi Ayyad University, Marrakech, Morocco, 1988.

59. Huvelin, P.; Permigeat, F. Soufre, pyrite, pyrrhotite. Notes Mém. Serv. Géol. Maroc 1980, 276, 227-243. 
60. Hakkou, R.; Benzaazoua, M.; Bussière, B. Acid mine drainage at the abandoned Kettara mine (Morocco): 1 . Environmental characterization. Mine Water Environ. 2008, 27, 145-159. [CrossRef]

61. Jaffal, M.; El Goumi, N.; Hibti, M.; Adama Dairou, A.; Kchikach, A.; Manar, A. Interprétation des données magnétiques du chapeau de fer de Laachach (Jebilets centrales, Maroc): Implications minières. Estud. Geol. 2010, 66, 171-180. [CrossRef]

62. Outigua, A.; Essaifi, A.; Lacinska, A.; Maacha, L.; Zouhair, M.; Outhounjit, M.; Essaoudi, M.; Badri, M. L'or dans les amas sulfurés des Jebilet (Hercynien, Maroc) l'exemple de Sidi Mbark (Draa Sfar Nord). In Proceedings of the 10th Edition of the Conference Internationale Magmatisme, Métamorphisme, et Minéralisations Assoociées, Ifrane, Morocco, 11-14 May 2017; pp. 110-111.

63. Eddebbi, A.; Saquaque, A.; Kersit, M.; Chbihi, A. L'amas sulphuré de Hajjar (Guemassa, Maroc). Chron. Rech. Min. 1998, 531-532, 45-53.

64. Bouabdellah, M.; Hibti, M.; Maacha, L.; Zouhair, M.; Velasco, F. Geologic, Hydrothermal, and Geochemical Relationships between Bimodal Magmatism and Massive Sulphide Mineralization in the Central Jebilet-Guemassa Province (Western Moroccan Hercynides). In Mineral Deposits of North Africa; Bouabdellah, M., Slack, F.J., Eds.; Springer International Publishing: Cham, Switzerland, 2016; pp. 437-459.

65. Franklin, J.M.; Sangster, D.F.; Lydon, J.W. Volcanogenic associated massive sulphide deposits. Econ. Geol. 1981, 75, 485-627.

66. Barrakad, A.; Huvelin, P.; Laforêt, C.; Perez, S.; Permingeat, F.; Picot, P. Minéraux de cobalt, d'étain, de bismuth, de sélénium, d'or et d'argent dans l'amas sulfuré à pyrrhotite de Sidi Embarek (Jebilet). Notes Mém. Serv. Géol. Maroc 1977, 37, 129-138.

67. Lagarde, J.L.; Michard, A. Stretching normal to the regional thrust displacement in a thrust-wrench shear zone, Rehamna Massif, Morocco. J. Struct. Geol. 1986, 8, 483-492. [CrossRef]

68. Essaifi, A.; Ballèvre, M.; Marignac, C.; Capdevila, R. Occurrence and significance of zincian ilmenite in low-pressure metapelites from central Jebilet (Morocco). C. R. Acad. Sci. Paris 2001, 333, 381-388.

69. Maacha, L.; Jaffal, M.; Jarni, A.; Kchikach, A.; Mouguina, E.; Zouhair, M.; Ennaciri, A.; Saddiqi, O. A contribution of airborne magnetic, gamma ray spectrometric data in understanding the structure of the Central Jebilet Hercynian massif and implications for mining. J. Afr. Earth Sci. 2017, 134, 389-403. [CrossRef]

70. Essaifi, A.; Capdevila, R.; Fourcade, S.; Lagarde, J.L.; Ballevre, M.; Marignac, C. Hydrothermal alteration, fluid flow and volume change in shear zones. The layered mafic-ultramafic Kettara intrusion (Jebilet Massif, Variscan belt, Morocco). J. Metamorph. Geol. 2004, 22, 25-43. [CrossRef]

71. Lusty, P.A.J.; Goodenough, K.M.; Essaifi, A.; Maacha, L. Developing the lithotectonic framework and model for sulphide mineralization in the Jebilet Massif, Morocco: Implications for regional exploration. In Mineral Resources in a Sustainable World, Proceedings of the 13th Biennial SGA Meeting, Nancy, France, 24-27 August 2015; André-Mayer, A.S., Cathelineau, M., Muchez, P.H., Pirard, E., Sindern, S., Eds.; Society for Geology Applied to Mineral Deposits (SGA): Genéve, Switzerland, 2015; pp. 1635-1638.

72. Fournier, M.; Felenc, J.; Hmeurras, M. Un amas sulfuré à pyrrhotine en milieu sédimentaire Kettara (Jebilet, Maroc). BRGM report. Unpublished work. 1987; 77p.

73. Hibti, M. Les amas Sulfurés des Guemassa et des Jebilet (Meseta Sud-Occidentale, Maroc): Temoins de L'hydrothermalisme Précoce Dans le Bassin Mesetien. Ph.D. Thesis, University Cadi Ayyad, Marrakech, Morocco, 2001.

74. Watanabe, $\mathrm{Y} .{ }^{40} \mathrm{Ar} /{ }^{39} \mathrm{Ar}$ geochronologic constraints on the timing of massive sulphide and vein-Type $\mathrm{Pb}-\mathrm{Zn}$ mineralization in the Western Meseta of Morocco. Econ. Geol. 2002, 97, 147-157. [CrossRef]

75. Saez, R.; Moreno, C.; Gonzalez, F.; Almodovar, G. Black shales and massive sulphide deposits: Causal or casual relationships? Insights from Rammelsberg, Tharsis, and Draa Sfar. Mineral. Depos. 2011, 46, 585-614. [CrossRef]

76. JICA (Japan International Cooperation Agency). Report on the Mineral Exploration in Marrakech-Tekna Area: Kingdom of Morocco. Phase 1; Japan International Cooperation Agency: Tokyo, Japan, 2003; 247p.

77. Ben Aissi, L. Contribution à L'étude Gîtologique des Amas Sulfurés Polymétalliques de Draa Sfar et de Koudiat Aïcha: Comparaison avec les Gisements de Ben Slimane et de Kettara (Jebilet Centrales, Maroc Hercynien). Ph.D. Thesis, University Cadi Ayyad, Marrakech, Morocco, 2008.

78. Vernon, R.H.; Peterson, S.R.; Foster, D. Growth and deformation of porphyroblasts in the Foothill Terrane, Central Sierra Nevada, California: Negotiating a microstructural minefield. J. Metamorph. Geol. 1991, 11, 203-222. [CrossRef] 
79. Passchier, C.W.; Trouw, R.A.J. Microtectonics; Springer: Berlin, Germany, 1996; pp. 176-182.

80. Perkins, W.G. Mount Isa lead-zinc orebodies: Replacement lodes in a zoned syndeformational copper-lead zinc system. Ore Geol. Rev. 1997, 12, 61-110. [CrossRef]

81. De Roo, J.A. The Elura Ag-Pb-Zn mine in Australia-ore genesis in a slate belt by syndeformational metasomatism along hydrothermal fluid conduits. Econ. Geol. 1989, 84, 256-278. [CrossRef]

82. Aerden, A.G.A.M. Microstructural timing of the Rosebery massive sulphides, Tasmania: Evidence for a metamorphic origin through mobilization of disseminated base metals. J. Metamorph. Geol. 1994, 12, 505-522. [CrossRef]

83. Vokes, F.M. A review of the metamorphism of sulphide deposits. Earth Sci. Rev. 1969, 5, 99-143. [CrossRef]

84. Gilligan, L.B.; Marshall, B. Textural evidence for remobilization in metamorphic environments. Ore Geol. Rev. 1987, 2, 205-229. [CrossRef]

85. Rziki, S. Le Gisement Polymétallique de Draa Sfar: Compilation et Modélisation Tridimentionnelle Géologique et Géophysique et Perspectives de Développement (Massif Hercynien des Jebilet Centrales, Maroc). Ph.D. Thesis, Cadi Ayyad University, Marrakech, Morocco, 2012.

86. Brown, D.; McClay, K.R. Deformation textures in pyrite from the Vangorda Pb-Zn-Ag deposit, Yukon, Canada. Mineral. Mag. 1993, 57, 55-66. [CrossRef]

87. Sangster, D.F. Precambrian volcanogenic massive sulphide deposits in Canada. A review. Can. Geol. Surv. Pap. 1972, 72-22, 44.

88. Sato, T. Behaviours of ore-forming solutions in seawater. Min. Geol. 1972, 22, 31-42.

89. Large, R.R. Chemical evolution and zonation of massive sulphide deposits in volcanic terrains. Econ. Geol. 1977, 72, 549-572. [CrossRef]

90. Lécolle, M. La Ceinture Sud-Ibérique: Un Exemple de Province à Amas Sulfurés Volcano-Sedimentaires. Ph.D. Thesis, University P. \& M., Curie, Paris, 1977.

91. Marzoqi, M. (Cadi Ayyad University, Marrakech, Morocco). Personal communication. 2013.

92. Roddaz, M.; Brusset, S.; Soula, J.C.; Beziat, D.; Benabbou, M.; Debat, P.; Driouch, Y.; Christophoul, F.; Ntarmouchant, A.; Deramond, J. Foreland basin magmatism in the western Moroccan Meseta and geodynamic inferences. Tectonics 2002, 21, 1043-1065. [CrossRef]

93. McPhie, J.; Allen, R.L. Submarine, silicic, syn-eruptive pyroclastic units in the Mount Read Volcanics, western Tasmania: Influence of vent setting and proximity on lithofacies characteristics. In Explosive Subaqueous Volcanism; White, J.D.L., Smellie, J.L., Clague, D.A., Eds.; Geophysical Monograph Series; American Geophysical Union: Washington, DC, USA, 2003; Volume 140, pp. 245-258.

94. Leblanc, M. Amas sulfuré formé par injection de sills dans des sédiments: Exemple d'Hajjar (Marrakech, Maroc). C. R. Acad. Sci. Paris 1993, 316, 499-504.

95. Le Corre, C.; Saquaque, A. Comportement d'un système pluton-encaissant dans un champ de déformation régional: Le granite de Bramram (Jebilet, Maroc hercynien). Bull. Soc. Géol. Fr. 1987, 4, 665-673.

96. Winchester, J.A.; Floyd, P.A. Geochemical magma type discrimination: Application to altered and metamorphosed basic igneous rocks. Earth Planet. Sci. Lett. 1976, 28, 459-469. [CrossRef]

97. Sun, S.; Mcdonough, W.F. Chemical and isotopic systematic of oceanic basalts: Implications for mantle composition and processes. In Magmatism in the Ocean Basins; Saunders, A.D., Norry, M.J., Eds.; Geological Society of London: London, UK, 1989; Volume 42, pp. 313-345.

98. Whalen, J.B.; Currie, K.L.; Chappell, B.W. A-type granites: Geochemical characteristics, discrimination and petrogenesis. Contrib. Mineral. Petrol. 1987, 95, 407-419. [CrossRef]

99. Eby, N.G. Chemical subdivision of the A-type granitoids: Petrogenetic and tectonic implications. Geology 1992, 20, 641-644. [CrossRef]

100. Lentz, D.R. Petrogenetic evolution of felsic volcanic sequences associated with Phanerozoic volcanic-hosted massive sulphide systems: The role of extensional geodynamics. Ore Geol. Rev. 1998, 12, 289-327. [CrossRef]

101. Lentz, D.R. Petrology, geochemistry and oxygen isotopic interpretation of felsic volcanic and related rocks hosting the Brunswick 6 and 12 massive sulphide deposits (Brunswick Belt), Bathurst Mining Camp, New Brunswick, Canada. Econ. Geol. 1999, 94, 57-86. [CrossRef]

102. Whalen, J.B.; Rogers, N.; van Staal, C.R.; Longstaffe, F.J.; Jenner, G.A.; Winchester, J.A. Geochemical and isotopic $(\mathrm{Nd}, \mathrm{O})$ data from Ordovician felsic plutonic and volcanic rocks of the Miramichi Highlands: Petrogenetic and metallogenic implications for the Bathurst Mining Camp. Can. J. Earth Sci. 1998, 35, 237-252. [CrossRef] 
103. Piercey, S. The setting, style, and role of magmatism in the formation of volcanogenic massive sulphide deposits. Mineral. Depos. 2011, 46, 449-471. [CrossRef]

104. Hart, T.R.; Gibson, H.L.; Lesher, C.M. Trace element geochemistry and petrogenesis of felsic volcanic rocks associated with volcanogenic massive $\mathrm{Cu}-\mathrm{Zn}-\mathrm{Pb}$ sulphide deposits. Econ. Geol. 2004, 99, 1003-1013. [CrossRef]

105. Kharbouch, F. Les Laves Dévono-Dinantiennes de la Meseta Marocaine: Étudepétrochimique et Implications Géodynamiques. Ph.D. Thesis, Bretagne Occidentale University, Brest, France, 1994.

106. Leat, P.T.; Jackson, S.E.; Thorpe, R.S.; Stillman, C.J. Geochemistry of bimodal basalt subalkaline/peralkaline rhyolite provinces within the Southern British Caledonides. J. Geol. Soc. Lond. 1986, 143, 259-273. [CrossRef]

107. Thorpe, R.S.; Leat, P.T.; Mann, A.C.; Howells, M.F.; Reedman, A.J.; Campbell, D.G. Magmatic evolution of the Ordovician Snowdon volcanic centre, North Wales (UK). J. Petrol. 1993, 34, 711-741. [CrossRef]

108. Brady, J.B. The role of volatiles in the thermal history of metamorphic terranes. J. Petrol. 1988, 29, 1187-1213. [CrossRef]

109. Essaifi, A.; Capdevila, R.; Lagarde, J.L. Metasomatic trondhjemites and tonalites: Examples in Central Jebilet (Hercynian, Morocco). J. Afr. Earth Sci. 2004, 39, 369-374. [CrossRef]

110. Haimeur, J. Contribution à L'étude de L'environnement Volcanosédimentaire et Minerai de Douar Lahjar (Guemassa, Maroc): Lithologie, Paléovolcanisme, Géochimie, Métallogénie. Ph.D. Thesis, Ecole Nationale Supérieure de Géologie, Nancy, France, 1988.

111. Lydon, J.W. Characteristics of volcanogenic massive sulphide deposits-Interpretations in terms of hydrothermal convection systems and magmatic hydrothermal systems. Boletin Geologico y Minero 1996, 107, 15-64.

112. McLeod, R.L.; Stanton, R.L. Phyllosilicates and associated minerals in some Paleozoic stratiform sulphide deposits of southeastern Australia. Econ. Geol. 1984, 79, 1-22. [CrossRef]

113. Bairouk, L. Géologie et Analyse des Paléofluides dans le Gisement de Sidi M’Barek (Massif des Jebilet, Maroc Hercynien). Master's Thesis, Cadi Ayyad University, Marrakech, Morocco, 2015.

114. Taylor, H.P. The application of oxygen and hydrogen isotope studies to problems of hydrothermal alteration and ore deposition. Econ. Geol. 1974, 69, 843-883. [CrossRef]

115. Munha, J.; Barriga, F.J.A.S.; Kerrich, R. High ${ }^{18} \mathrm{O}$ ore-forming fluids in volcanic hosted base metal massive sulphide deposits: Geologic ${ }^{18} \mathrm{O} /{ }^{16} \mathrm{O}$ and $\mathrm{D} / \mathrm{H}$ evidence for the Iberian Pyrite Belt; Crandon, Wisconsin; and Blue Hill, Maine. Econ. Geol. 1986, 81, 530-552. [CrossRef]

116. Ohmoto, H. Stable isotope geochemistry of ore deposits. Rev. Mineral. 1986, 16, 491-560.

117. Pisutha-Arnond, V.; Ohmoto, H. Thermal history, chemical and isotopic compositions of the ore-forming fluids responsible for the Kuroko massive sulphide deposits in the Hokuroki district of Japan. Econ. Geol. Monogr. 1983, 5, 523-558.

118. Sheppard, M.F. Characterization and isotopic variations in natural waters. Rev. Mineral. 1986, 16, $165-183$.

119. N'diaye, I. Contrôle Structural, Percolation de Paleofluides et Minéralisation Polymétallique: L'exemple du Système Hydrothermal de Kettara (Jebilet Centrales, Maroc). Ph.D. Thesis, Cadi Ayyad University, Marrakech, Morocco, 2016.

120. Ouguir, H. Étude Métallogénique, Conditions Physicochimiques et Géochimie Isotopique de Soufre de la Minéralisation Sulfurée: Gîte de Douar Lahjar (Guemassa, Maroc). Master's Thesis, Institut National Polytechnique de Lorraine, Nancy, France, 1987.

121. Velasco, F.; Sanchez-Espana, J.; Boyce, A.J.; Fallick, A.E.; Saez, R.; Almodovar, G.R. A new sulfur isotopic study of some IPB deposits: Evidence of a textural control on sulfur isotope composition. Mineral. Depos. 1998, 34, 4-18. [CrossRef]

122. Velasco-Acebes, J.; Tornos, F.; Wiedenbeck, M.; Kidane, A.T.; Velasco, F.; Delgado, A. Isotope geochemistry tracks the maturation of submarine massive sulfide mounds (Iberian Pyrite Belt). Mineral. Depos. 2019, in press. [CrossRef]

123. Ohmoto, H.; Rye, R.O. Isotopes of sulfur and carbon. In Geochemistry of Hydrothermal Ore Deposits, 2nd ed.; Barnes, H.L., Ed.; Wiley: New York, NY, USA, 1979; pp. 509-567.

124. Hoefs, J. Stable Isotope Geochemistry, 6th ed.; Springer: Berlin/Heidelberg, Germany, 2009; pp. 1-285.

125. Solomon, M.; Rafter, T.A.; Jensen, M.L. Isotope studies on the Rosebery, Mount Farrell and Mount Lyell ores, Tasmania. Mineral. Depos. 1969, 4, 172-199. [CrossRef] 
126. Kajiwara, Y. Sulfur isotope study of the Kuroko-ores of Shakanai $N^{\circ} 1$ deposits, Akita Prefecture. Jpn. Geochem. J. 1971, 4, 157-181. [CrossRef]

127. Kajiwara, Y.; Date, J. Sulfur isotope study of Kuroko-type and Kieslager-type strata-bound massive sulphide deposits in Japan. Geochem. J. 1971, 5, 133-150. [CrossRef]

128. Lambert, I.B.; Donnelly, T.H.; Dunlop, J.S.R.; Groves, D.I. Stable isotopic compositions of early Archean sulphate deposits of probable evaporitic and volcanogenic origin. Nature 1978, 276, 808-810. [CrossRef]

129. Ripley, E.M.; Ohmoto, H. Mineralogic, sulfur isotope, an fluid inclusion studies of the stratabound copper deposits at the Raul mine, Peru. Econ. Geol. 1977, 72, 1017-1041. [CrossRef]

130. Bryndzia, L.T.; Scott, S.D.; Farr, J.E. Mineralogy, geochemistry and mineral chemistry of siliceous ore and altered footwall rocks in the Uwamuki 2 and 4 deposits, Kosaka mine, Hokuroku district, Japan. Econ. Geol. Monogr. 1983, 5, 507-522.

131. Alt, J.C. A sulfur profile through the Troodos ophiolite, Cyprus: Primary composition and the effect of seawater hydrothermal alteration. Geochim. Cosmochim. Acta 1994, 58, 1825-1840. [CrossRef]

132. Shanks, W.C.; Bischoff, J.L.; Rosenbauer, R.J. Seawater sulfate reduction and sulfur isotope fractionation in basaltic systems: Interaction of seawater with sulphate at $200-350{ }^{\circ} \mathrm{C}$. Geochim. Cosmochim. Acta 1981, 45, 1977-1995. [CrossRef]

133. Edwards, A. Lead Isotope Results from the Marrakech-Amizmiz-Imi N'Tanout-Chichoua Area, Morocco. Managem Report. Unpublished work. 1989; 9p.

134. Marcoux, E. La Géochimie Isotopique du Plomb Appliquée à la Propection des Jebilet-Guemassa (Anti-Atlas Marocain). Managem Report. Unpublished work. 2004; 17p.

135. Marcoux, E. Lead isotope systematics of the giant massive sulphide deposits in the Iberian Pyrite Belt. Mineral. Depos. 1998, 33, 45-58. [CrossRef]

136. Stacey, J.S.; Kramers, J.C. Approximation of terrestrial lead isotope evolution by a two-stage model. Earth Planet. Sci. Lett. 1975, 26, 207-221. [CrossRef]

137. Cumming, G.L.; Richards, J.R. Ore lead isotope ratios in a continuously changing Earth. Earth Planet. Sci. Lett. 1975, 28, 155-171. [CrossRef]

138. Zartman, R.E.; Doe, B.R. Plumbotectonics-the model. Tectonophysics 1981, 75, 35-162. [CrossRef]

139. Sato, K. Unilateral isotopic variation of Miocene ore leads from Japan. Econ. Geol. 1975, 70, 800-805. [CrossRef]

140. Fehn, U.; Doe, B.R.; Delevaux, M.H. The distribution of lead isotopes and the origin of Kuroko ore deposits in the Hokuroku district, Japan. Econ. Geol. Monogr. 1983, 5, 488-506.

141. Allen, R.L.; Weihed, P. The Global VMS Research Project Team, Global comparisons of volcanic-associated massive sulphide deposits. In The Timing and Location of Major Ore Deposits in an Evolving Orogen; Blundell, D.J., Neubauer, F., von Quadt, A., Eds.; Geological Society London Special Publication: London, UK, 2002; pp. 13-38.

142. Dewey, J.F. Transtension in Arcs and Orogens. Int. Geol. Rev. 2002, 44, 402-439. [CrossRef]

143. Ohmoto, H.H.; Skinner, B.J. The Kuroko and related volcanogenic massive sulphide deposits: Preface and summary of new findings. Econ. Geol. Monogr. 1983, 5, 1-8.

144. Allen, R.L.; Svenson, S.-Å. 1.9 Ga volcanic stratigraphy, structure, and Zn-Pb-Cu-Au-Ag massive sulphide deposits of the Renström area, Skellefte District, Sweden. In Svecofennian Ore-Forming Environments: Volcanic-Associated $\mathrm{Zn}-\mathrm{Cu}-\mathrm{Au}-\mathrm{Ag}$, Intrusion-Associated $\mathrm{Cu}-\mathrm{Au}$, Sediment-Hosted $\mathrm{Pb}-\mathrm{Zn}$, and Magnetite-Apatite Deposits of Northern Sweden; Allen, R.L., Martinsson, O., Weihed, P., Eds.; Society of Economic Geologists Guidebook Series 33; Society of Economic Geologists: Littleton, CO, USA, 2004; pp. 65-88.

145. Tornos, F.; Casquet, C.; Relvas, J.; Barriga, F.; Saez, R. The relationship between ore deposits and oblique tectonics: The SW lberian Variscan Belt. In The Timing and Location of Major Ore Deposits in an Evotving Orogen; Blundell, D.J., Neubauer, F., von Quadt, A., Eds.; Geological Society London Special Publication: London, UK, 2002; pp. 179-198.

146. Chernicoff, C.J.; Richards, J.P.; Zappettini, E.O. Crustal lineament control on magmatism and mineralization in northwestern Argentina: Geological, geophysical, and remote sensing evidence. Ore Geol. Rev. 2002, 21, 127-155. [CrossRef]

147. Tornos, F.; Casquet, C.; Relvas, J. Transpressional tectonics, lower crust decoupling and intrusion of deep mafic sills: A model for the unusual metallogenesis of SW Iberia. Ore Geol. Rev. 2005, 27, 133-163. [CrossRef] 
148. Qian, G.; Xia, F.; Brugger, J.; Skinner, W.M.; Bei, J.F.; Chen, G.; Pring, A. Replacement of pyrrhotite by pyrite and marcasite under hydrothermal conditions up to $220^{\circ} \mathrm{C}$ : An experimental study of reaction textures and mechanisms. Am. Mineral. 2011, 96, 1878-1893. [CrossRef]

149. Wilkin, R.T.; Barnes, H.L. Pyrite formation by reactions of iron monosulphides with dissolved inorganic and organic sulfur species. Geochim. Cosmochim. Acta 1996, 60, 4167-4179. [CrossRef]

150. Gonzales, F.; Moreno, C.; Saez, R.; Clayton, G. Ore genesis of the Tharsis mining district (Iberian pyrite belt): A palynological approach. J. Geol. Soc. Lond. 2002, 159, 229-232. [CrossRef] 